NASA Technical Memorandum 102492

\title{
Self-Lubricating Polymer Composites and Polymer Transfer Film Lubrication for Space Applications
}

Robert L. Fussaro

Lewis Research Center

Cleveland, Ohio

February 1990

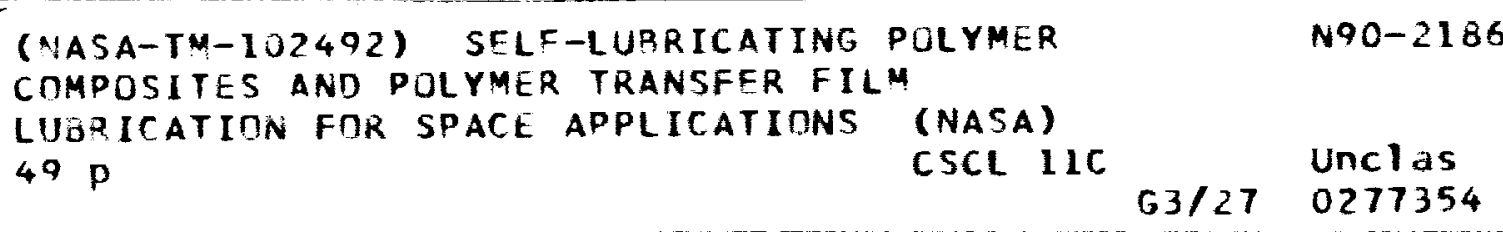


\. 


\section{SELF-LUBRICATING POLYMER COMPOSITES AND POLYMER TRANSFER \\ FILM LUBRICATION FOR SPACE APPLICATIONS \\ Robert L. Fusaro \\ National Aeronautics and Space Administration \\ Lewis Research Center \\ Cleveland, Ohio 44135}

\section{ABSTRACT}

The use of self-lubricating polymers and polymer composites in space is somewhat limited today. In general, they are only used when other methods are inadequate. There is potential, however, for these materlals to make a significant impact on future space missions if properly utilized. This paper surveys some of the different polymers and fillers used to make self-lubricating composites. It delves into the mechanisms of composite lubrication and wear, the theory behind transfer film lubricating mechanisms, and some factors which affect polymer composite wear and transfer. In addition, some of the current space tribology application areas for self-lubricating polymer composites and polymer transfer are mentioned. INTRODUCTION

Lubrication in space presents most of the problems that are encountered in terrestrial applications and also some unique problems that are not encountered there. If at all possible, designers tend to use liquids to provide lubrication in space. In some instances though, liquids can not be utillzed. For example, they would not be used where contamination by a liquid is a problem, at cold temperatures where llquids freeze or become too viscous to pour; and at high temperatures where they thermally breakdown. In these cases, solid lubricants must be employed.

The most common way to utilize solid lubricants is to apply them as films to metallic surfaces. The solid lubricant can be burnished (rubbed) onto the 
surface, vapor deposited by such techniques as sputtering or ion plating, or incorporated into a binder system which contains a liquid carrier and then applied as a film by spraying, dipping, etc. The binder material does not necessarily have to be a lubricant, its principle purpose is to bind solid lubricant particles to the metallic surface after the liquid carrier is removed.

Another way to utilize solid lubricants is to make the sliding mechanism or a component of the mechanism into a self-lubricating composite. A self-lubricating composite is a material that consists of a reinforcing matrix, one or more solid lubricant additives, and various other constituents which are added for binding components together, for environmental stabilization, etc. An example of where a self-lubricating composite might be used is in the cage of a rolling element bearing.

The most common solid lubricants employed in terrestrial applications are the layer lattice compounds, graphite and molybdenum disulfide and the polymer, polytetrafluoroethylene (PTFE). Graphite usually is not used for space applications since it needs absorbed vapor to be a good lubricant. Molybdenum disulfide on the other hand works much better in the absence of absorbed vapors, thus it is a widely used solid lubricant in space. It does have a couple of problems and those are: its life can be shortened if it slides too long in air before it is used in vacuum and long time storage can sometimes induce decomposition to molybdenum oxide.

In general, PTFE works well both in presence of vapors and in a vacuum environment. However, PTFE also has a problem in that it tends to cold flow under load and must be incorporated into some sort of a binder system to keep it in place. To date, there have not been many other polymer materials widely utilized for space applications. However, some recent work by Fusaro (1987), 
has Indicated that some of the polyimide polymers also possess excellent lubrication properties in a vacuum environment but they must be properly conditioned first. More research needs to be conducted on these materials before they will become space qualifled, however.

Since there is vast potential for the greater use of polymers in space lubrication, it is the purpose of this paper to review the current understanding of the how's and why's of polymer lubrication. This will be done by looking at the properties of polymers and the environmental factors that can effect their friction, wear, and transfer performance. Some different polymers, fillers for polymers, and means of incorporating polymers or polymer composites into silding mechanisms will be discussed. In addition, the paper will review the current use of polymers and polymer composites as space lubricants.

POLYMER STRUCTURE

In order to understand the physical properties of polymers, considerable research has been conducted on their molecular structure. Nearly all polymers used today for lubrication or mechanical purposes are organic polymers. They consist of very large molecules which contain carbon atoms as the main component in their backbone. Polymers tend to grow into long chains which are bullt-up of repeating small chemical units called monomers. A polymer can grow to a molecular weight of several million, depending on polymerization conditions. The length of the chain can affect the mechanical properties of the polymer.

Polymers can be classifled as being thermoplastics or thermosets. Thermoplastics have a lack of cross-linking between the long-chain molecules, while thermosets are highly cross-linked. Polymers may be also classified as being either amorphous or crystalline; however, even in well-crystallized 
polymers, amorphous regions have been found to exist. Likewise, in amorphous polymers, crystalline regions have been observed. Undoubtedly, the interaction of these regions, as well as the transformation from one phase to another, can influence the physical properties of a polymer.

In order to explain the varlous physical properties of polymers, several models of polymer structure have been proposed. Some of the most prominent models are (1) random coll, (2) fringed micelle, (3) folded chain, (4) extended chain, and the (5) molecular domain. The model most widely accepted for crystalline polymers is the folded chain. It is based on the fact that complex aggregates of molecules, called spherulites, exist throughout the entire mass of solld polymers. X-ray diffraction studies have shown these spherulites to be composed of platelike lamellae. These lamellae are characterized by a rather uniform thickness, of the order of 5 to $100 \mathrm{~nm}$. Scanning electron microscopy and $x$-ray diffraction has shown that the lamellae consist of regularly folded chains which are perpendicular to the lamellae surface, thus the reason for the model has been designated folded-chain.

Figure 1 gives a schematic representation of a polymer which has been crystallized under different conditions, and has attained different degrees of order (Hoffman, 1966). Folded chalns, extended chains, and the amorphous nature of the polymer can be seen. If the distance between the folds becomes greater than $200 \mathrm{~nm}$, the crystal is then designated as an extended chain crystal. When no folds are present, the term fully extended-chain crystal is applied.

There are several ways that the extended-chain crystals can form. They can be formed from the melt by regulating crystallization conditions, they can be formed in a polymer solid by annealing it at temperatures above the crystallization temperature, or they can be formed by applying a mechanical stress to a polymer so as to induce chain unfolding. 
Two models for chain unfolding by mechanical deformation of lamellae have been proposed (see references in Fusaro, 1975). The first proposes that, by plastic deformation, the chains simply unfold in the direction of the applied force. The second proposes that, by shearing deformation, the chains gradually become tilted by twisting and slipping and thus become progressively oriented in the direction of the force. Whichever the case, it appears that the extended chain structure is the preferred structure when low friction and wear are desired. For a detailed list of references on polymer structure see Fusaro, 1975.

\section{SELF-LUBRICATING POLYMER COMPOSITES}

There are several reasons for adding other materials to polymers to make composites. One reason is to increase the polymer's load carrying capacity. Fibers or particulates can be used to accomplish this. In general, fiber composites tend to have better load carrying capacity than particulate composites.

A second reason for making a composite, is to include lubricating additives to help lower the friction coefficient and the wear rate. One must be careful with these additives though, since they can also lower the load carrying capability because of the lubricating additives easy slip planes. This is true especially when particulate lubricating additives are used. When higher load carrying capacity and good lubrication are desired, composites are often formulated using both reinforcing fibers and lubricating particulate additives, or sometimes with a combination of nonlubricating and lubricating fibers. Fibers can be chopped into short pieces and randomly dispersed throughout the polymer matrix or continuous fibers can be used to form two- or three-dimensional mats which are then filled with the polymer.

A third reason for additives is to increase the composite's thermal conductivity. Polymers in general are not good thermal conductors, thus to 
reduce the heat bulld-up in sliding contacts, a thermally conductive material may be added.

Some possible polymers and additives commonly incorporated into the making of polymer composites as given by The CRC Handbook of Lubrication (Booser, 1984) are listed in Table 1. Polymers are classified as thermoplastics or as thermosets. Additives are classified as reinforcement, friction and wear reducing, or thermal conducting.

Some particulate additives, such as graphite, are classified both as friction and wear reducing and as thermal conducting additives, but one would not want to use graphite as a friction and wear reducing additive for space applications since graphite needs absorbed vapors to be a good lubricant. Similarly, in afr, graphite (carbon) fibers work very well to lower the friction and wear characteristics and to increase the load carrying capability; but one would not want to use these fibers in vacuum for lubrication purposes because of the absorbed vapor need. Some polymer composites and where they are used in space applications are listed in Table 2. MECHANISMS OF POLYMER COMPOSITE LUBRICATION AND WEAR

In order for a solid body polymer or polymer composite to provide lubrication, it must be able to support the dynamic stresses induced by the applied load and the tangential friction stresses. If the polymer/polymer composite can not support these stresses, it will wear rapidly (plastically deform, brittlely fracture, etc.). In some cases, this will cause catastrophic fallure. In other cases, the composite may wear rapidiy only until the contact area increases to the point where the polymer will support the decreased dynamic stresses and then transformation to a milder form of wear will occur. Stress is probably the most important parameter to consider with self-lubricating composites, a part must be designed so that the 
self-lubricating composite will be able to support the dynamic stress of sliding.

In the cases where a polymer or polymer composite has adequate load carrying capability, different types of wear can occur depending on the polymer and additives used and the conditions of sliding. It has been observed by this author that in order to provide the best lubrication, some sort of a "shear layer" must develop between the sliding surfaces. This shear layer is necessary to reduce the adhesive and the "plowing" interactions that takes place between relatively moving surfaces. In addition to reducing friction, this layer can also reduce the stresses in bulk of the polymer body. In general, it has been observed that the thinner the shear layer the better.

Some polymer materials have the ability to form a shear layer on their OWn. PTFE chains can be drawn out on the surface to form an extended chain type of crystal structure which is conducive to low shear and thus low friction (Pooley and Tabor, 1972). However, bulk PTFE does not have good load carrying capability and thus in order to achieve long life, PTFE must be incorporated into a composite, both as a solid body and as a coating or film.

Some polyimides (a class of long chain polymers with repeating imide groups as an integral part of the chain) also have the ability to form this thin shear layer at the surface but can only do so under vacuum conditions or at temperatures above $100^{\circ} \mathrm{C}$ in air (Fusaro, 1978 and 1988). The reason appears to be that water molecules can hydrogen bond to the polymer chains and Inhibit their ability to be drawn out on the surface into an extended chain molecule. When run under vacuum conditions or at high temperatures, friction coefficients of less than 0.02 have been obtained with these polyimides and the wear rates have been extremely low (Fusaro, 1988). Flgure 2 shows a 
have been extremely low (Fusaro, 1988). Figure 2 shows a polyimide wear surface evaluated at $150^{\circ} \mathrm{C}$ which shows a very thin surface layer $(<1 \mu \mathrm{m})$ in the process of spalling (Fusaro, 1978). Most of the surface is very smooth and featureless, but with repeated passes localized areas, such as that shown can debond from the surface.

The advantage of the polyimides over PTFE is that the load carrying capability remains very high even though the friction drops to very low values. Thus, additives are of ten not necessary, especially for space applications. A problem with polyimide is that it is like a sponge in air and absorbs coplous amounts of water vapor. The absorbed water vapor tends to cause the polyimides to give higher friction coefficient values. Merely putting the polyimide in vacuum does not remove the water vapor. The water has to be driven out by heating in vacuum or the high friction (a friction coefficient of 0.2 or higher occurs with absorbed water) must be endured until the surface layer containing the water is worn away. Currently it is not known how thick this water containing layer is or how much water vapor is involved. This is an area is for research if polyimide is to become a viable lubricant in space.

Figure 3 (Fusaro, 1988) plots the friction coefficient as a function of sliding distance in air and in vacuum for a commercially avallable polyimide (Vespel SP 1). In $a / r$, the friction coefficient starts out at about 0.20 and increases to an average value of about 0.47 . In vacuum, the friction also starts off at 0.20 but eventually decreases to a value less than 0.02 after $40 \mathrm{kc}$ of sliding. At $100 \mathrm{rpm}$, this represents $400 \mathrm{~min}$ of sliding time to wear away the absorbed moisture layer, and obtain low friction.

UHMWPE (UItra-High-Molecular-Weight-Polyethylene) is another polymer which possesses good load carrying capabllity and can shear on the surface via 
a very thin shear layer. However, UHMWPE does not have good high temperature stablility (begins to melt at $101^{\circ} \mathrm{C}$ ). It does have excellent potential for lower temperature use, however. The material is the prevalent material used in artificial hip joints today. The author is not aware of many (if any) applications where it is currently used in space.

The quality of the shear layer formed determines how well the composite will provide lubrication. In order for it to endure it must remain bonded to the bulk of the polymer and it must have a quality which the author has designated "flowing into itself," i.e., as the counterface passes over the layer, molecules in the layer move, but they slide over one another in such manner that no apparent differences in the layer occurs. Fallure of the layer can occur by fatigue (debonding) of a small area of the layer from the bulk or by the gradual flow of a small portion of the layer out of the contact area.

Usually the formation of this lubricative surface layer promotes the formation of a transfer film to the counterface. As long as the transferred layer remains thin, shear will either take place within or between the two layers. If the transfer tends to bulld-up into too thick a layer, there is a tendency for higher adhesive forces and localized stresses to occur which can increase the friction and cause the wear processes at the surface of the composite to change. Instead of the shear within the layer, larger wear particles are produced at the surface of the composite and more severe wear occurs.

Figure 4 shows photomicrographs of a metallic counterface pin which slid against an UHMWPE polymer disk at two different speeds (Fusaro, 1982). At slow speeds, ridges of heavy transfer occurred. The ridges tended to cause localized wear (grooves) on the polymer disk surface and erratic friction. At faster speeds, the polymer did not form these ridges, the transfer tended to 
be thin and continuous. This resulted in a very smooth polymer surface wear surface and less erratic friction.

Sometimes it is necessary to "run in" a polymer/composite under a lower load to first establish the shear layer or transfer film layer. Once a layer is established, the bulk material will be able to support a higher unit load due to the lower tangential contribution of the sliding component of stress. TRANSFER FILM LUBRICATING MECHANISMS

In the lubrication mechanism mentioned above, shear takes place within: the shear layer on the surface of the polymer/polymer composite, the transfer film on the counterface, or between the two. A mechanism involving a double transfer lubricating film has been devised to lubricate ball bearings. In this mechanism, the cage of the ball bearing is made out of the polymer composite material; the rest of the bearing is made of metal. The assumption behind this lubrication process is that the cage transfers material to the balls, which in turn transfers material to the inner and outer races. Figure 5 shows a sketch of how this transfer film mechanism operates.

Kannel and Dufrane, 1986 have studied the effect of load in an ambient air atmosphere on the double transfer of a PTFE composite (Rulon-A and 5 percent $\mathrm{MoS}_{2}$ ) in a device like that shown in Fig. 6. They found as the load (contact stress) between the ball and the ring (race) was increased, the roughness of the wear track decreased slightly. They also found at a mean stress level of $1.38 \mathrm{GPa}$ the transfer film was insufficient to prevent roughening of the surfaces (Fig. 7). Their experiments imply that there is a limiting stress for effective transfer film lubrication with PTFE composites, at least in an air environment.

Because of the load limitations, this double transfer film lubrication process ordinarlly has only been used to lubricate lightly loaded, low speed 
ball bearings. However, it has also been used to lubricate the bearings of the Space Shuttle Main Engines (SSME) turbopumps, where it has been only minimally successful. This will be discussed in more detail later in the paper.

ADVANTAGES AND DISADVANTAGES OF POLYMERS IN A SPACE

Some of the advantages of using self-lubricating polymer composites in a space environment are low outgassing, no liquid lubricants needed thus low contamination potential, relatively low coefficient of friction, lightweight, low cost and simplicity of design. Some disadvantages are high coefficient of thermal expansion, lower load capacity, higher wear rates than liquid lubrication metals, limited dimensional stability due to thermal growth, and poor thermal conductivity.

FACTORS AFFECTING POLYMER COMPOSITE WEAR AND TRANSFER Load/Stress

As mentioned previousiy, in order for a polymer composite to function as a solld body lubricant it must be able to support the load and the tangential stresses induced by sliding. It has been observed that there are two regimes of polymer film wear and composite wear dependent on load/stress (Fusaro, 1982). Some might call these regimes mild and severe wear. Essentially low loads lead to mild wear but high loads can cause severe wear. The severe wear regime is characterized by brittle fracture or severe plastic deformation. The mild wear regime is characterized by the formation of the "shear layer" at the composite surface, the formation of a thin transfer film and a delamination type of wear process of the shear layer.

Figure 8 shows photomicrographs which illustrate the two wear processes. Shown is a polymide-bonded graphite fluoride film $(0.0025 \mathrm{~cm}$ thick) which was able to support the load and act like a sollid body. Mild wear was 
characterized by the spallation of very thin surface layers $(<1 \mu m$ thick), while severe wear was characterized by brittle fracture of the surface 1 to $6 \mu \mathrm{m}$ deep. The depth of brittle fracture was dependent on load, area of contact and the build-up of thick transfer films.

In the mild wear regime, wear rate (wear per unit sliding distance) was found to increase linearly as a function of increasing load. While in the severe wear regime, wear rate was found to increase exponentially as a function of load and could at some point even be catastrophic.

\section{Contact Area}

Contact area is important from two points of view. First, the contact area will determine the projected contact stress. If the load can not be reduced, one way of reducing the contact stress is to increase the projected contact area, this lowers the stress and promotes sliding in the mild regime of wear. Figure 9 plots polymide-bonded graphite fluoride film wear rate as a function of silding duration for four different counterface contact areas sliding against the film under constant load. The figure shows that as contact area increased (and the resulting stresses decreased) the wear decreases (Fusaro, 1982). However, a larger contact area and lower stresses can cause other problems as mentioned below.

The second effect of contact area is on transfer film formation. The contact area can affect the amount and type of transfer taking place. As mentioned previously what is desired is a very thin "plastically flowing" transfer film. If the area of contact becomes too large, instead of the transfer flowing across the metallic counterface surface, it will have a tendency to build up and form ridges which can cause high localized stresses and higher adhesion (Fig. $4(2)$ ). This will lead to higher friction and severe wear. Thus it is important to design a part with the correct match-up of load and contact area. 


\section{Sliding Speed}

The sliding speed can have a couple of effects on polymer composites. First, high sliding speeds can produce high temperatures due to frictional heating. This may cause the polymer or the polymer composite additives to degrade. However, in some cases higher temperatures might be beneficial to the lubricating process. It could help drive out absorbed water vapor or increase the temperature above some molecular relaxation temperature which in turn could provide greater mobility to the polymer molecules, this will be discussed later in the paper.

Second, polymers are composed of molecular chains. In order to develop a surface shear film and a transfer film, the molecular chains must have time to reorlent. If one slides too fast over these unoriented chains, instead of reorienting they will fracture, leading to the production of large wear particles and high wear. Thus, it is important to appropriately choose the sliding speed for each particular polymer to ensure the best results. Absorbed Gases/Vapors

Solld lubricants are very sensitive to the atmosphere in which they are slid. Graphite needs absorbed gases or vapors to make it a good lubricant; while molybdenum disulfide functions much better in absence of absorbed gases or vapors, which makes it an excellent lubricant in vacuum. Polymer composites can be even more affected by the atmosphere in which they slide. This is partly because they may contain solid lubricant additives that are sensitive to atmospheric vapors and also because they themselves can be affected by atmospheric vapors.

PFTE seems to be best in this regard, it is not highly affected by atmospheric conditions. But polyimides, polyamides, epoxies, and in general any polymer which has a free hydrogen bond in its structure are highly affected 
by absorbed vapors, especially water vapor. It is postulated that the water, which hydrogen bonds to the polymer chains, restricts the molecules ability to flow on the surface to form an extended chain crystal structure; and consequently the thin lubricating surface layer does not form. Thus, these types of polymers, especially the polyimides, tend to lubricate much better in a vacuum (Fusaro, 1988).

Counterface Topography

The material counterface that slides against a polymer composite is very important in determining the friction and wear characteristics of that composite. For example, if the counterface is too rough, it can abrade the composite and not allow a shear film or transfer film to form. The effect of counterface materlal type and surface roughness on the wear rate (Fig. 10) and friction coefficient (Fig. 11) of graphite-fiber-reinforced polyimide composites sliding against different materials with different surface roughnesses was studied by fusaro, 1986.

All the materials, except the glass and vitallium, were given surface finishes using the same procedure. A wide variety of surface roughnesses were obtained. It was evident that to obtain a very smooth surface with a given material that a specific surface treatment needs to be developed for a particular material. Thus, from this study, it could not be ascertained whether or not the material type had an effect on the friction and wear properties. The study did demonstrate that the smoother the counterface, the lower the wear rate.

In addition, it was found that there are some factors to watch out for. A root mean square (rms) or a centerline average ( $C L A$ ) low value of roughness does not always mean the surfaces are smooth. It was found that over-polishing the $440 \mathrm{CHT}$ stainless steel tended to polish away the softer matrix material 
of the metal and left hard carbide particles protruding above the surface. When the polymer composite slid against this surface it was severely abraded. Figure 12 shows a photomicrograph of this metallic surface with polymer composite wear debris around the carbide particles. This illustrates that it is Important to consider the complete topography of the surface rather than just a numerical value of surface roughness.

Surface finish or material type did not initially affect the friction coefficient. Friction tended to start out at the same value; but as sliding distance increased, transfer characteristics changed and so did the friction coefficients. The best results were obtained with pyrex glass which was the smoothest surface and produced extremely thin transfer films. It should be pointed out that these tests were done in air and equivalent results may not occur in vacuum for this composite material since graphite is involved, but it is belleved the basic principles about surface roughness and transfer do apply. Cleanliness

Cleanliness is an extremely important parameter in dealing with polymer composites. As mentioned previously, absorbed gases and vapors can affect polymer friction and wear, likewise adsorbed liquids can have similar deleterious effects. Dirt can even have more disastrous effects. Dirt can embed into the surface of the composite and turn it into and abrasive material instead of a lubricant. Figure 13 shows a photomicrograph of a small hard inclusion which got imbedded into an UHMWPE polymer solid (Fusaro, 1982). The particle acted like an abrasive and wore a groove in the $440 \mathrm{C}$ stainless steel (Rockwell C-60) counterface.

Temperature and Molecular Relaxations

Most polymers possess molecular relaxations, i.e., at certain temperatures varlous molecular segments are freed up and given the capability 
for movement. For example, the glass transition temperature is the temperature above which the movement of the main chain in the polymer obtains its greatest degree of freedom (or conversely the temperature below which the motion is frozen) and thus the polymer obtains a great deal of plasticity above this temperature. Other relaxations can occur at lower temperatures in polymers which relate to movements of molecular segments, side chains, etc. These movements or restrictions of movements can seriously affect the tribological properties of a polymer. They can restrict small movement in the chains which can restrict the formation of the thin "shear layer."

One method for determining the temperatures at which relaxations occur in polymers is a technique called torsional braid analysis (TBA). Fusaro, 1975 attempted to correlate the relaxations as determined by TBA techniques to the friction properties of a commercially avallable polyimide (PI 4701). The results of that study are shown in Fig. 14 where the logarithmic decrement as determined by TBA and friction coefficient are plotted as a function of sliding distance. Essentially four TBA relaxation peaks were found. The most pronounced peak was the peak which correlated to the glass transition temperature. When the friction coefficient values were compared to these peaks, it was found that there was a big friction change correlating to a $\alpha$-peak (the glass transition temperature) and one correlating to the $\beta-\mathrm{H}_{2} \mathrm{O}$ peak (due to absorbed water vapor). It was interesting that heating the polyimide to $500{ }^{\circ} \mathrm{C}$ in dry argon increased the glass transition temperature to $500{ }^{\circ} \mathrm{C}$ and decreased the friction coefficient in this temperature region ( 300 to $500^{\circ} \mathrm{C}$ ) also. Later studies have shown that if the absorbed water vapor can be removed from this polyimide, low friction coefficients can also be obtalned below $50{ }^{\circ} \mathrm{C}$ (Fusaro, 1988).

Another example of molecular relaxation effects occurs with PTFE. PTFE has a couple of relaxations that occur below ambient temperature. It is known 
that at lower temperatures, the friction and wear properties of PTFE are not as exceptional as they are at or above amblent $\left(\sim 25^{\circ} \mathrm{C}\right)$ temperature. The most likely cause of decreased friction and wear properties is the restriction of motion of molecular segments of the PTFE chain.

In addition to relaxation effects which occur at various temperatures in polymers, temperature can effect the lubricating properties of the additives in polymer composites. Additives might desorb gases at certain temperatures or even decompose. Temperature can also affect the bonding between the additives and the polymer matrix. These are some of the ways that temperature can effect polymer composite friction and wear. Very few polymer materials, if any, have friction and wear properties independent of temperature.

Radiation

The kinds of radiation in space can be categorized into electromagnetic radiation and particulate radiation. Electromagnetic radiation includes infrared, visible, ultraviolet, x-rays and gamma rays. Particulate radiation includes cosmic rays, trapped electrons and protons, and solar flares.

The intensity of electromagnetic radiation varies inversely as the distance from the sun. At the Earth's distance from the sun, 50 percent of the energy lies in the infrared and radio frequency regions, 40 percent in the visible region, and 10 percent in the ultraviolet and $x$-ray regions. of these radiations ultraviolet and $x$-rays can do the most damage to polymers. Such radiation can result in the ionization of many materials and can excite electrons to a high energy state resulting in excited molecules. Absorption of ultraviolet radiation in organic polymers can lead to cross-linking, chain scission, or random breaking of other bonds. Infrared radiation can thermally degrade a polymer and degradation could be accelerated by the combined effects of the above. 
Particulate radiation comes from the sun, deep space, and the Van Allen radiation belts. The primary effects on materials from particulate radiation are those of ionization and displacement. Ionization can occur from gamma rays, electrons, and protons. Displacement occurs only for protons. Polymers exposed to particulate radiation can experience chain scission, polymerization and cross-linking. In general, aromatlc groups in the side chains of a polymer increase stability to ionizing radiation while aromatic groups in the main chain decrease this stability (Flom 1966).

Current data on ultravollet and other radiation exposures of materials is limited to one year and only for a minimum number of materials. Lubricant changes on exposure to this environment have not been adequately assessed, but wlll certainly be an important factor for polymer self-lubricating composites exposed to this environment (Leger 1987).

\section{Atomic Oxygen}

Atomic oxygen, the major constituent in a low Earth orbit environment, has just recently been recognized as being an important consideration in the design of long-lived spacecraft (Leger 1987). Experiments on two shuttle missions STS-5 and STS-8 provide essentially all of the quantitative data to date. Carbon, silver, and osmium have been found to react quickly enough to produce macroscopic changes in the structure. Carbon reacts to form volatile oxides. Silver forms heavy oxide layers which result in the loss of material by flaking and spallation. Because of this, one would probably not want to use these materlals in polymer composites exposed to atomic oxygen.

Polymers such as epoxies, polyurethanes, and polyimides were also found to be reactive with atomic oxygen. The reaction efficiency did not seem to be strongly dependent on chemical structure, however. Some representative reaction efficiencies are shown in Table 3. The efficiencies are expressed as 
the volume of material lost per incident oxygen atom. The data indicates the use of self-lubricating polymers and their additives for long duration use in space needs to be examined very closely if the polymer is to undergo long duration exposure to atomic oxygen.

POLYMER COMPOSITE SPACE TRIBOLOGY APPLICATIONS

Gears

In general, polymer composites gears currently are only considered for use in light load, precision space applications. The composites gears are run dry against stainless steel or against anodized aluminum alloys. For gears, there is a need for stiffness and hardness as well as for low friction and wear. This limits the choice of composites. For example, PTFE must be heavily reinforced to be usable as a gear material. Other polymers considered for gears are polyimides, polyamides (nylons), polyamide-imides, and polyacetals. Glass fibers are used for reinforcement, and MoS 2 is of ten added to lower the friction coefficient. On occasion a polyimide with MoS 2 powder additive has been used to make gears for use in space. This material is easy to machine and very good surface finishes can be obtained, thus it has been found suitable for fine-pitch gears.

Another material that seems to be well sulted for gears is a high pressure laminate of cotton fabric and a phenolic polymer. This material has been found to be particularly tough and restlient when used to make gears. A problem with it though is that it must be machined from sheet and thus the surface quality is not as good as desired (Steven 1983). The tribological behavior of some plastic gears as determined by Steven, 1983, are shown in Table 4.

Good results have been reported by the European Space Tribology Lab (ESTL) for both polyimide and polyacetal lightly loaded gears running against 
stainless steel, titanium, or aluminum (Todd 1983). Their work indicates that polyimide gives the lowest wear rate of all polymers they tested. They also demonstrated that by incorporating carbon fibers into the polyacetal polymer, lower wear rates could be obtained as compared to the next polymer; the wear rate was still not as low as that obtained with polyimide, however. They also Indicate that the maximum load for these materials should be 11 mited to $10 \mathrm{~N} / \mathrm{mm}$ tooth width.

Slow Speed Oscillatory or Rotary Motion Ball Bearings

Spacecraft have many components where the surfaces either oscillate or rotate slowly. Typical applications involve bearings which support scanning mirrors, extendable booms, tachometer shafts, despin satellites, etc. Oscillatory motion is that motion in which a shaft turns in one angular direction and then returns over the same arc on efther a periodic or intermittent basis. For boom rotations the angular velocities are generally slow $\left(<6^{\circ} / \mathrm{sec}\right)$ and equal in both directions. For scanning mirrors the rotation in one direction is usually very slow $\left(<2^{\circ} / \mathrm{sec}\right)$ followed by a rapid return $\left(<60^{\circ} / \mathrm{sec}\right)$.

Vest (1963) evaluated a composite consisting of PTFE + MoS $2+$ glass fibers as a retainer materlal for oscillating bearings and found the bearings were still in good condition after $10000 \mathrm{hr}\left(1 \times 10^{6}\right.$ cycles) of testing. He also evaluated them at $100 \mathrm{rpm}$ under full circular motion and found the bearings also to be in reasonably good shape after $12600 \mathrm{hr}\left(7.6 \times 10^{7}\right.$ cycles $)$. Both tests used a $7 \mathrm{~N}(1-1 / 2 \mathrm{lb})$ radial load. Increasing the load to $23 \mathrm{~N}$ (5 $\mathrm{lb}$ ) in the unidirectional test produced considerably more wear debris over the same running period as the $7 \mathrm{~N}$ loaded bearing and bearing surfaces were rated as poor, Indicating the load carrying capacity of the bearing had been exceeded. 
Christy, 1982 has reported that some PTFE-MOS 2 composite cages, which are used in gimbal ball bearings that dither over a $4^{\circ}$ rotation angle, have produced transfer to the balls in the form of lumps. When these gimbals have to slew in $50^{\circ}$ steps, this transfer produces high torque peaks. This points out the importance of using cage materials that produce uniform transfer films.

The European Space Agency (ESA) has been using this self-lubricating composite (PTFE/glass fibers/MoS2) for many years with much success as a cage material in small, lightly loaded, slow speed rotary motion ball bearings (Briscoe and Todd 1983). They have determined that this composite performs well as long as the Hertzian contact stress does not exceed $1200 \mathrm{MN} / \mathrm{m}^{2}$ at $20{ }^{\circ} \mathrm{C}$. They have tried the composite without $\mathrm{MOS}_{2}$, but find it works better with the $\mathrm{MOS}_{2}$ additive. The $\mathrm{MOS}_{2}$ appears to prevent the transfer from becoming too thick. As mentioned previously, thick transfer (especially lumpy) produces erratic torque. As Vest found, the fallure in these tests was associated with the wearing-out of the cage, creating large quantities of debris.

Table 5 compares some torque results from bearing tests using metallic cages coated with sputtered $\mathrm{MOS}_{2}$ or ion-plated lead, and for PTFE-composite cages (Briscoe and Todd, 1983). The sputtered MOS $_{2}$ bearing falled between 0.7 to $3.6 \times 10^{+6}$ revolutions but provided low torque noise. The lon-plated lead cage and PTFE-composite cage provided approximately equivalent results except that the torque was slightly steadier and the peak-to-peak torque (noise) was greater for lon-plated lead.

Roberts (1986), has compared the torque properties of ion-plated lead cages, PTFE-composite cages and PTFE-composite cages which were sputtered with $\mathrm{MoS}_{2}$. Figure 15 summarized the results of that work. Plotted here are typical "torque bands" for $20 \mathrm{~mm}$ bore angular-contact ball bearings lubricated with each of te above mentioned lubricants. The values represent ambient 
temperature tests on bearings axfally loaded to $40 \mathrm{~N}$ and rotated at speeds up to $200 \mathrm{rpm}$ in high vacuum. Torque values were presented in bands since performance has been observed to vary from component to component. The figure indicates that the sputtered $\mathrm{MoS}_{2}$ film dramatically lowered the torque and torque nolse for the PTFE-composite cage under these test conditions. Cryogenic Ball Bearings

There are many current and future space missions which will require instruments that must be cooled to cryogenic temperatures. These include infrared detectors, superconducting devices and several telescopes (infrared, x-ray, gamma-ray and high energy) (Gould and Roberts, 1989). In addition, high speed turbopumps, like those used on the Space Shuttle Main Engines (SSME) operate with the cryogen passing directly through the bearings. 011s and greases solidify at these temperatures, therefore the only viable alternative is solld lubrication.

NASA has been interested in developing self-lubrtcating composite materials for cryogenic applications since the late 1950's/early 1960's (Wisander, 1959 and 1961). In addition, NASA has spent considerable effort at the same time developing the bearing technology necessary for utilizing these self-lubricating composite materials in a cryogenic environment (Scibbe and Anderson, 1962; Cunningham and Anderson, 1965; Brewe, 1966; Zaretsky, 1967; Scibbe, 1968).

Ball bearings used in liquid cryogen turbopumps have several basic material and design requirements. Among them are the selection of: (1) the ball-race material, (2) the self-lubricating cage material (that provides lubricant to the load carrying surfaces by a transfer mechanism and that provides a long wear $11 \mathrm{fe})$, (3) a cage design that has adequate strength and sufficlent clearances at cryogenic temperatures, and (4) the internal design 
and geometric factors that minimize heat generation with the bearing due to ball spin.

The work in the 1950's and 1960's to address the above requirements was conducted at NASA Lewis Research Center over a 10 year period. Ball bearing internal design for mintmum heat generation was obtained from an experimental program where the bearings were operated at high speeds submerged in a liquid hydrogen bath (Scibbe and Anderson, 1962). The cage material and design information was obtained from an experimental bearing program run in $33 \mathrm{~K}$ gasous hydrogen (Brewe 1962, Zaretsky 1967). These tests were run in gasous hydrogen because it was felt that this would subject the bearings to a more severe operating condition than liquid hydrogen and might approximate the end condition more closely. Ball and race material selection was based on experiments conducted in liquid nitrogen and liquid hydrogen (Martin 1959).

The best lubricant found in these early studies for use at cryogenic temperatures (and it is still the predominantly used material today) was polytetrafluoroethylene (PTFE). It was found however that PTFE had poor strength properties and tended to cold flow even under the lightest loads. It also had poor thermal conductivity which is a problem for high speed bearings, where heat generation can be detrimental to successful bearing operation. Thus the need was established to compound it with other materials to give it more desirable properties. Some of the early formulations used were laminated glass cloth with a PTFE binder, glass-fiber-filled PTFE, glass-fiber-molybdenum disulfide-filled PTFE, and bronze-filled PTFE (Brewe, 1966). Table 6 lists some properties of those composites.

The above four composite cages were evaluated in $40-\mathrm{mm}$ ball bearings. The bearings were operated in $33 \mathrm{~K}$ gaseous hydrogen at 20000 rpm under a $200 \mathrm{lb}$ thrust load for running times up to $10 \mathrm{hr}$. A proflle tracing technique 
was used to study the formation and life histories of the transfer films provided from the cages to the bearing's inner races. Figure 16 shows typical surface profiles (obtained at various times during the life of the bearing) from tests using the glass cloth-filled PTFE composite cage.

It can be seen after 284 min a fairly good film of lubricant has been deposited on the inner race. However, some scratches can be seen in the profile. These were believed to have been caused by abrasion of the glass fibers in a cage material. With continued running, the film tended to break down and the wear of the inner race surface accelerated. Race wear increased with time and after $10 \mathrm{hr}$ the bearing was near fallure.

It was believed that the cause of the film breakdown and large amount of race wear was caused by the abrasion of the glass fibers which become shredded from the cage material. A postulated abrasive-wear process is illustrated in Fig. 17. Shown are alternate layers of glass cloth and PTFE. The ball rotates and wears away the softer PTFE material. After a short time the PTFE is worn away exposing the glass fibers to the rubbing action of the balls. Continued rubbing caused the glass fibers to shred and embed into the transferred PTFE film. This make the film an abrasive and soon wears away any protecting PTFE transfer film on the race with resultant high wear of the race.

The other three PTFE composites provided good transfer film production and adequate lubrication for the $10 \mathrm{hr}$ test duration. Although some scratches were found on the inner races with the composite that contained Mos2, no severe wear occurred as was found in the previously mentioned case. The bronze-PTFE cage provided very thin transfer and no scratches were observed on the races.

Percent weight loss of the four PTFE composite cages is plotted as a function of time in Fig. 18. All four cages showed very low weight loss. The 
maximum weight loss was 0.89 percent for one of the bronze cages. This wear was attributed to the fact that it had an eccentric shape and rubbed heavily on the inner-race. The maximum weight loss for the rest of the cages was 0.25 percent.

Cunningham and Anderson (1965) experimentally evaluated the same PTFE composite retainer materials under radial loads of 450 to $2700 \mathrm{~N}$ (100 to $600 \mathrm{lb}$ ) and at speeds of up to $30000 \mathrm{rpm}$ in $40-\mathrm{mm}$-bore ball bearings. The DN values (bearing bore in millimeters times shaft speed in rpm) was up to 1.2 million. Some of the results of that work is given in Fig. 19, where retainer wear is plotted as a function of retainer sliding distance for three of the PTFE composite materials. In these tests, the laminated glass cloth-PTFE binder exhibited the best wear resistance. Based upon these experiments and previous work, this material was chosen as the SSME bearing cage material. The material seems to work well in the liquid hydrogen pumps, but not as well in liquid oxygen (LOX) pumps. Problems have occurred with the LOX pump bearings in that after a few launches the bearings have experienced excessive wear and must be replaced. Since it is desired that the SSME turbopumps be able to operate for multiple launches between overhauls, better cage materials are being sought (Kannel, 1988) (Poole, 1988). One of the problems encountered is developing a cage material that will provide the strength of the laminated glass cloth-PTFE binder cage, yet not be abrasive.

The European Space Tribology Laboratory (ESTL) has been evaluating the torque produced by various cage materials in vacuum (but not in the cryogenic media itself) from $300 \mathrm{~K}$ down to $20 \mathrm{~K}$ (Gould and Roberts, 1989). They found that the mean torque and the torque nolse of bearings lubricated with composite cages containing either PTFE or MoS 2 increases with cryogenic coolling down to $20 \mathrm{~K}$. Bearings fitted with lead-containing ball retainer 
cages and lubricated with an lon-plated lead film showed torque levels that remained unaffected on decreasing temperature.

CONCLUDING REMARKS

The current state-of-the-art of self-lubricating polymer composites and polymer transfer film lubrication has been summarized. The paper discusses many of the factors that affect polymer and polymer composite friction, wear, and transfer. However, many of the factors stated in the paper which influence the tribological properties of these materials have only been evaluated in air environments. The results may not be exactly the same in a vacuum environment. Similarly, accelerated testing machines give an indication of how certain parameters affect friction and wear, but again the results achieved may be different when the lubricants are incorporated into the real end-use device. Certainly more work needs to be done on these materials in a vacuum environment and in end-use mechanisms to ascertain their suitablilty for space use.

In addition, work needs to be done on new concepts of bearing design which utilizes the special properties that polymers possess. New bearing and self-lubricating composite materials need to be assessed, especially in relation to transfer film formation and growth. While the transfer film mechanism for the lubrication of rolling element bearings has been successful for lightly loaded bearings, it seems reasonable to speculate that this may not necessarily be the best way to utllize self-lubricating polymer materlals for space lubrication. The question arises how do we design a bearing to optimally utilize these materials? The potential is there for low friction, long life self-lubricating polymer composite bearings, the problem is to develop the technology for properly employing them and for space qualifying them. 


\section{REFERENCES}

Bisson E.E. Lubrication and Bearing Problems in the Vacuum of Space. NASA TM $\underline{X-52208}, 1966$.

Barber S.A., Dufrane K.F., Kannel J.W., Merriman T.L., and Rosenfield A.R. Bearing Materials Studies for Space Shuttle Main Engine (SSME) Cryogenic Turbopump Application. NASA CR-171507, 1985.

Barber S.A, Kannel J.W., and DuFrane K.F. Evaluation of Transfer Films of Salox $M$ on $440 C$ for HPOTP Bearing Cage Applications, Task 119. NASA CR-179020, 1986.

Barber S.A. and Kannel J.W. Evaluation of Slip-Traction Characteristics of Polymeric Transfer Films. J. Tribology, 1988, 110, 670-673.

Boes D.J. Long Term Operation and Practical Limitations of Dry, Self-Lubricated Bearings From 1 $\times 10^{-5}$ Torr to Atmospheric. Lubr. Eng., 1963, $19,137-142$.

Boes, D.J. and Bowen P.H. Friction-Wear Characteristics of Self-Lubricating Composites Developed for Vacuum Service. Proceedings of Space Lubrication Conference, Co-Sponsored by NASA and ASLE, New York, 1968, ASLE Paper $\underline{\text { 63AM-6A-2 }}$ (Conf. Proc. Ava 11. NTIS, AD-439844).

Bohner J.J. and Gardos M.N. The Effect of Composition on the Load-Speed Time-Dependent Oscillatory Wear of Selected Polymerlc Self-Lubricating Composites. Lubr. Eng., 1987, 43(6) 347-350.

Booser R.E., ed. CRC Handbook of Lubrication, Vol. 2, Theory and Design, CRC Press, Boca Raton, FL, 1984.

Bowen P.H. Dry Lubricated Bearings for Operation in Vacuum. ASLE Trans., $1962,5(2), 315-326$.

Bowen P.H. Solid Lubrication of Gears and Bearings in a Space Environment. ASLE Trans., 1964, 7(3), 227-235.

Brainard W.A. and Buckey D.H. Adhesion and Friction of PTFE in Contact with Metals as Studied by Auger Spectroscopy. Field Ion and Scanning Electron Microscopy. Wear, 1973, 26, 75-93.

Brewe D.E., Scibbe H.W., and Anderson W.J. Fllm-Transfer Studies of Seven Ball-Bearing Retainer Materials in $60^{\circ} \mathrm{R}\left(33^{\circ} \mathrm{K}\right.$ ) Hydrogen Gas at 0.8 Million DN Value. NASA TN D-3730, 1966.

Brewe D.E., Coe H.H., and Scibbe H.H. Cooling Studies With High-Speed Ball Bearings Operating in Cold Hydrogen Gas. ASLE Trans., 1969, 12(1), 66-76.

Briscoe M. and Todd M.J. Considerations on the Lubrication of Spacecraft Mechanisms. The 17th Aerospace Mechanisms Symposium, NASA CP-2273, National Aeronautics and Space Administration, Washington, D.C., 1983, pp. 19-37.

Brown R.D., Burton R.A., and Ku P.M. Long Duration Lubrication Studies in Simulated Space Vacuum. ASLE Trans., 1964, 7(3), 236-248. 
Buck V. Self-Lubricating Polymer Cages for Space-Proofed Bearings: Performance and Roundness. Tribology Int., 1986, 19(1), 25-28.

Buckley D.H. Friction and Wear Characteristics of Polyimide and Filled Polyimide Composites in Vacuum $\left(10^{-10} \mathrm{~mm} \cdot \mathrm{Hg}\right)$. NASA TN-D-3261, 1966.

Butner M. and Shoemaker M. Surface Characteristics of Liquid Oxygen Cooled Ball Bearings. Advanced Earth-to-Orbit Propulsion Technology 1986, Vol. 2, NASA-CP-2437-VOL-2, R.J. Richmond and S.T. Wu, eds., National Aeronautics and Space Administration, Washington, D.C., 1986, pp. 293-310.

Christy R.I. Ory Lubrication for Rolling Element Spacecraft Parts. Tribology Int., 1982, 15(5), 265-271.

Cunningham R.E. and Anderson W.J. Evaluation of 40-mm Bore Ball Bearings Operating in Liquid Oxygen at DN Values to $1.2 \mathrm{Mi} 11$ ion. NASA TN D-2637, 1967.

Delaat F.G.A, Shelton R.V., and Kimzey J.H. Status of Lubricants for Manned Spacecraft. Lubr. Eng., 1967, 23(4), 145-153.

Evans D.C. The Influence of an Abrasive Filler on the Wear Properties of PTFE-Base Composites. ASLE Proceedings 2nd International Conference on Solid Lubrication, American Society of Lubrication Engineers, Park Ridge, IL, 1978, pp. 202-211.

Evans D.C. and Senfor G.S. Self-Lubricating Materials for Plain Bearings. Tribology Int., 1982, 15(5), 243-248.

Evans D.C. The Influence of Abrasive Fillers on the Wear Properties of Polytetrafluoroethylene (PTFE)-Based Composites. RAE-TR-75144, Royal Atrcraft Establishment, Farnborough, England, 1976.

Fleischaver P.D. and Bauer R. The Influence of Surface Chemistry on MoS 2 Transfer Film Formation. ASLE Trans., 1987, 30(2), 160-166.

Flom D.G. Survey of Aerospace Requirements for Bearings and Lubricants. Lubr. Eng., 1966, 22(10), 415-423.

Fusaro R.L. Friction Transition in Polyimide Films as Related to Molecular Relaxations and Structure. NASA TN D-7954, 1975.

Fusaro R.L. Effect of Atmosphere and Temperature on Wear, Friction, and Transfer of Polyimide Films. ASLE Trans., 1978, 21(2), 125-133.

Fusaro R.L. Mechanisms of Lubrication and Wear of a Bonded Solid-Lubricant Film. ASLE Trans., 1981, 24(2), 191-204.

Fusaro R.L. Effect of Load, Area of Contact and Contact Stress on the Wear Mechanisms of a Bonded Solid Lubricant Film. Wear, 1982, 75, 403-422. 
Fusaro R.L. Effect of Sliding Speed and Contact Stress on the Tribological Properties of UItra-High-Molecular-Weight Polyethylene. NASA TP-2059, 1982.

Fusaro R.L. Polyimides - Tribological Properties and Their Use as Lubricants. Polyimides: Synthesis, Characterization, and Applications, Vol. 2, K.L. Mittal, ed., Plenum Press, New York, 1984, pp. 1053-1080.

Fusaro R.L. Counterface Effects on the Tribological Properties of Polyimide Composites. Lubr. Eng., 1986, 42(11), 668-675.

Fusaro R.L. Evaluation of Several Polymer Materlals for Use as Solid Lubricants in Space. STLE Tribology Trans., 1988, 31(2), 174-181.

Jones J.R. and Gardos M.N. Friction and Wear Characteristics of Lubricative Composites in Air and in Vacuum. Lubr. Eng., 1971, 27(2), 47-53.

Jones J.R. and Gardos M.N. Transfer Film Formation by Lubricative Composites. ASLE Proceedings, 1st International Conference on Solid Lubrication, $J$. Boyd, ed., American Society of Lubrication Engineers, Park Ridge, IL, 1971.

Gardos M.N. Theory and Practice of Self-Lubrlcated, Oscillatory Bearings for High-Vacuum Applications, Part I- Selection of Self-Lubricating Composite Retainer Materlal. Lubr. Eng., 1981, 37(11), 641-656.

Gardos M.N. Self-Lubricating Composites for Extreme Environment Applications. Tribology Int., 1982, 15(5), 273-283.

Gould S.G. and Roberts E.W. The In-Vacuo Torque Performance of Dry-Lubricated Ball Bearings at Cryogenic Temperatures. The 23rd Aerospace Mechanisms Symposium, NASA CP-3032, National Aeronautics and Space Administration, Washington, D.C., 1989, pp. 319-333.

Harris C.L. and Warwick M.G. Lubrication of Bearings and Gears for Operation in a Space Environment. Lubrication in Hostile Environments, Proceedings $\frac{1968-69, \text { Vol. 183, Part 3i, Institution of Mechanical Engineers, London, }}{1969 \text {, pp. 39-49. }}$

Hoffman J.D., Williams G., and Passaglia E. Analysis of the Alpha, Beta, and Gamma Relaxations in Polychlorotrifluore thylene and Polyethylene:

Dielectric and Mechanical Properties. Transitions and Relaxations in Polymers, R.F. Boyer, ed., J. Polym. Sc i.Pt.C, Polym. Symp., 1966, 14,

Jackson E.G. Lubrication in Space Vehicles. Wear, 1962, 5, 417-434.

Johnson R.L. and Buckley D.H. Lubricants and Mechanical Components of Lubrication Systems for Space Environment. Lubr. Eng., 1966, 22(10),
408-414.

Kannel J.W. and Dufrane K.F. Rolling Element Bearings in Space. The 20th Aerospace Mechanisms Symposium, NASA CP-2423, National Aeronuatics and Space Administration, Washington, D.C., 1986, pp. 121-132. 
Kannel J.W., Dufrane K.F., Barber S.A., and Gleeson J. Development of Improved Self-Lubricating Cages for SSME HPOTP Bearings. Advanced Earth-to-Orbit Propulsion Technology 1988, Vol. I, NASA CP-3012-VOL-1, R.J. Richmond and S.T. Wu, eds., National Aeronautics and Space Administration, Washington, D.C., 1988, pp. 175-189.

Kannel J.W., DuFrane K.F., and Zugaro F.F. Study of Methods for Applying and Enhancing Transfer Film Coatings of Polytetrafluoroethylene (PTFE) to Space Shuttle Main Engine (SSME) High Pressure Oxygen Turbo Pump (HPOTP) Bearings. NASA CR-161916, 1981.

Kannel J.W. and DuFrane K.F. Transfer Film Evaluation for Shuttle Engine Turbopump Bearings. NASA CR-161672, 1981.

Kirkpatrick D.L. and Young W.C. Evaluation of Dry Lubricants and Bearings for Spacecraft Applications. Proceedings of the 3rd Aerospace Mechanisms Symposium, NASA CR-97758, National Aeronautics and Space Administration, Washington, D.C., 1968, pp. 77-84.

Klaus F. Friction and Wear of Polymer Composites. Elsevier, New York, 1986.

Lancaster J.K. Estimation of the Limiting PV Relationships for Thermoplastic Bearing Materials. Tribology, 1971, 4(2), 82-86.

Lancaster J.K. Dry Bearings: A Survey of Materials and Factors Affecting Their Performance. Tribology, 1973, 6(6), 219-251.

Lancaster J.K, and Moorhouse P. Etched-Pocket, Dry-Bearing Materials. Iribology Int., 1985, 18(3), 139-148.

Lancaster J.K. Transfer Lubrication for High Temperatures: A Review. $\underline{\mathrm{J}}$ Tribology, 1985, 107(4), 437-443.

Lancaster J.K., Play D., Godet M., Verrall A.P., and Waghorne R. Third Body Formation and the Wear of PTFE Fibre-Based Dry Bearings. J. Lubr. Technol., $1980,102(2), 236-246$.

Lauer J.L., Bunting B.G., and Jones W.R. Jr. Investigation of Frictional Transfer Films of PTFE by Infrared Emission Spectroscopy and Phase-Looked Ellipsometry. STLE Tribology Trans., 1988, 31(2), 282-288.

Leger L.J. and Dufrane K. Space Station Lubrication Considerations. The 2lst Aerospace Mechantsms Symposium, NASA CP-2470, National Aeronautics and Space Administration, Washington, D.C., 1987, pp. 285-294.

Lewis P., Murray S.F., Peterson, M.B., and Esten H. Lubricant Evaluation for Bearing Systems Operating in Spatial Environments. ASLE Trans., 1963, 6(1), 67-79.

Makinson K.R. and Tabor D. The Friction and Transfer of Polytetrafiuoroethylene. Proc. Roy. Soc. (London) A, 1964, A281, 49-61. 
Martin C., Sallleau J., and Pesenti P. Experiments with Self-Lubricating Composites for Space Bearings. La Recherche Spatlale, 1974, 13, 20-24.

McConnell B.D. and Mecklenburg K.R. Solid Lubricant Compacts - An Approach to Long Term Lubrication Performance in Space. Lubr. Eng., 1977, 33(10), 544-551.

Mecklenburg K.R. Performance of Ball Bearings in Air and Vacuum With No Added Lubrication. AFML-TR-72-73, June 1972 (Avail. NTIS, AD-746034).

Meeks C.R. Theory and Practice of Self-Lubricated Oscillatory Bearings for High-Vacuum Applications, Part II - Accelerated Life Tests and Analysis of Bearings. Lubr. Eng., 1981, 37(11), 657-667.

Murray S.F. A Review of the Applications of Composite Self-Lubricating Materials. ASLE Proceedings, 2nd International Conference on Solid Lubrication, American Society of Lubrication Engineers, Park Ridge, IL, 1978, pp. 158-163.

Murray S.F., Lewis P., and Babecki A.J. Lubricant Life Tests on Ball Bearings for Space Applications. ASLE Trans., 1966, 9(4), 348-360.

Naerheim Y., Stocker P.J., and Lumsden J.B. Determination of the SSME High Pressure Oxidizer Turbopump Bearing Temperature. Advanced Earth-to-Orbit Propulsion Technology 1988, Vol. 1, NASA CP-3012-VOL-1, R.J. Richmond and S.T. Wu, eds., National Aeronautics and Space Administration, Washington, D.C., 1988, pp. 102-109.

Oike M., Nosaka M., Kikuchi N., and Watanabe Y. Experimental Study on Durability of the Self-Lubricating Ball Bearings for Liquid Hydrogen Turbopumps. 14th International Symposium on Space Technology and Science, M. Nagatomo, ed., AGNE Publishing Inc., Tokyo, Japan, 1984, pp. 151-158.

Pepper S.V. Auger Analysis of Films Formed on Metals in Sliding Contact with Halogenated Polymers. J.Appl. Phys., 1974, 45(7), 2947-2956.

Poole W.E. and Bursey R.W. Jr. Pratt and Whitney Cryogenic Turbopump Bearing Experience. Advanced Earth-to-Orbit Propulsion Technology 1988, Vol 1, NASA CP-3012-VOL-1, R.J. Richmond and S.T. WU, eds., National Aeronautics and Space Administration, Washington, D.C., 1988, pp. 190-199.

Mecklenberg K.R. Performance of Lubricants: 011 s and Greases on Wear Tests, Compact Materials in Ball Bearings, and Sputtered Coatings on Gas-Bearing Coupons. AFML-TR-78-126, Air Force Materlals Laboratory, Sept 1978 (Ava11. NTIS, AD-AO63987).

Pooley C.M. and Tabor D. Friction and Molecular Structure: The Behaviour of Some Thermoplastics. Proc. Roy. Soc., (London) A, 1972, A329, 251-274.

Roberts W.H. Some Current Trends in Tribology in the UK and Europe. Tribology Int., 1986, 19(6), 295-311.

Roller K.G. Lubrication for Space Environments. Aerospace Century XXI: Space Flight Technologies, G.W. Morgenthaler and W.K. Tobiska, eds., Univelt, Inc., San Diego, CA, 1987, pp. 1011-1018. 
Roussel M. Composite Self-Lubricating Materials for Space Applications - Ball Bearing Cages. CNES-NT-25, Centre National d'Etudes Spatiales, Toulouse, France, 1975.

Roussel M., Martin C., and Sailleau J. Composite Self-Lubricating Materials for Space Applications. Space Tribology, T.D. Nguyen and B.T. Battrick, eds., European Space Agency, Paris, France, 1975 (Avail. NTIS, 75N24005).

Scibbe H.W. Bearings and Seals for Cryogenic Fluids. NASA TM X-52415, 1968.

Scibbe H.W. and Anderson W.J. Evaluation of Ball-Bearing Performance in Liquid Hydrogen at DN Values to 1.6 Million. ASLE Trans., 1962, 5(1), 220-232.

Scibbe H.H., Brewe D.E., and Coe H.H. Lubrication and Wear of Ball Bearings in Cryogenic Hydrogen. NASA TM X-52476, 1968.

Scibbe H.K., Glenn D.C., and Anderson W.J. Friction Torque of Ball Bearings in Vacuum with Seven Polytetrafluoroethylene Composition Retainer Materials. NASA TN D-4355, 1968.

Smith G.R. and Vest C.E. Lubrication of a Spacecraft Mechanism Using the Transfer Film Technique. Lubr. Eng., 1971, 27(12), 422-427.

Stevens K.T. The Tribology of Gears for Satellite Applications. First European Space Mechanisms and Tribology Symposfum, ESA-SP-196, T.D. Guyenne and J.J. Hunt, eds., European Space Agency, Paris, France, 1983, pp. 131-146.

Stevens K.T. and Todd M.J. Parametric Study of Solid-Lubricant Composites as Ball-Bearing Cages. Tribology Int., 1982, 15(5), 293-302.

Sitch D. Self Lubricating Rolling Element Bearings, With PTFE-Composite Cages. Tribology, 1973, 6(6), 262-263.

Tanaka K. Friction and Wear of Glass and Carbon Fiber-Filled Thermoplastic Polymers. J. Lubr. Technol., 1977, 99(4), 408-414.

Todd M.J. Solld Lubrication of Ball Bearings for Spacecraft Mechanisms. Tribology Int., 1982, 15(6), 331-337.

Vest C.E. and Ward B.W. Jr. Evaluation of Space Lubricants Under Oscillatory and Slow Speed Rotary Motion. Lubr. Eng., 1968, 24(4), 163-172.

Vest C.E. Transfer Film Lubrication of Ball Bearings. MTR-764-001, Materials Technology Report, NASA Goddard Space Flight Center, Dec. 1972 (Avail. NTIS, AD-921658L).

Vest C.E. Evaluation of Several Additional Dry Lubricants for Spacecraft Applications. Lubr. Eng., 1974, 30(5), 246-251. 
Wheeler D.R. The Transfer of Polytetrafluoroethylene Studied by X-Ray Photoelectron Spectroscopy. Wear, 1981, 66, 355-365.

Wisander D.W., Maley C.E., and Johnson R.L. Wear and Friction of Filled Polytetrafluoroethylene Compositions in Liquid Nitrogen. ASLE Trans., 1959, 2(1), 58-66.

Hisander D.W., Ludwig L.P., and Johnson R.L. Wear and Friction of Varlous Polymer Laminates in Liquid Nitrogen and in Liquid Hydrogen. NASA TN D-3706, 1966.

Young W.C. and Clauss F.J. Lubrication for Spacecraft Applications. Lubr. Eng., $1966,22(6), 219-227$.

Zaretsky E.V., Scibbe H.W., and Brewe D.E. Studies of Low and High Temperature Cage Materials. NASA TM X-52262, 1967.

TABLE 1. - PLASTICS AND FILLERS FOR SELF-LUBRICATING COMPOSITES (Jooser, 1984)

\begin{tabular}{|c|c|}
\hline Plastics and Fillers & Max Useful Temp, ${ }^{\circ} \mathrm{C}$ \\
\hline $\begin{array}{l}\text { Thermoplastics } \\
\text { Polyethylene (high MW and UHMW) } \\
\text { Polycetal (homo- and Co-polymer) } \\
\text { Nylons (types } 6,6.6,11 \text { ) } \\
\text { Poly (phenylene sulfide) } \\
\text { Poly (tetrafluoroethylene) } \\
\text { Poly (p-oxybenzodte) }\end{array}$ & $\begin{array}{r}80 \\
125 \\
130 \\
-200 \\
275 \\
300\end{array}$ \\
\hline Thermosetting & \\
\hline $\begin{array}{l}\text { Phenolics } \\
\text { Cresylics } \\
\text { Epoxies } \\
\text { Silicones } \\
\text { Polyimides }\end{array}$ & $\begin{array}{l}\sim 150 \\
\sim 150 \\
-200 \\
-250 \\
\sim 300\end{array}$ \\
\hline Reinforcements & \\
\hline $\begin{array}{l}\text { Glass fibers } \\
\text { Asbestos fibers } \\
\text { Textiles (polyester, "Nomex", cotton) } \\
\text { Mica }\end{array}$ & $\begin{array}{l}--- \\
---- \\
----\end{array}$ \\
\hline $\begin{array}{l}\text { Friction and wear reducing additives } \\
\text { Graphite } \\
\text { Molybdenum disulfide } \\
\text { Polytetrafluoroethylene (PTFE) } \\
\text { Metal oxides } \\
\text { Sllicon flulds }\end{array}$ & $\begin{array}{l} \\
---- \\
---- \\
---- \\
----\end{array}$ \\
\hline Thermal conductivity adjunctives & \\
\hline $\begin{array}{l}\text { Bronze } \\
\text { Graphite } \\
\text { Silver }\end{array}$ & --- \\
\hline
\end{tabular}


TABLE 2. - SOME SELF-LUBRICATING COMPOSITES AND THEIR POSSIBLE USES IN SPACE

\begin{tabular}{|l|l|}
\hline \multicolumn{1}{|c|}{ Composite Type } & \multicolumn{1}{|c|}{ Uses } \\
\hline PTFE/glass fiber & Bearing cages \\
PTFE/glass fiber/Mos2 & Bearings, cages, gears \\
Polyacetal homopolymer/co-polymer & $\begin{array}{l}\text { Bearings, cages, gears } \\
\text { bushings, brakes } \\
\text { Bearings, cages, gears } \\
\text { Reinforced phenolics } \\
\text { Polylmide/MoS }\end{array}$ \\
PTFE/Woven glass fiber/resin & Bearing cages, gears \\
PTFE/Bronze sinter & Bushings, rotating nuts \\
\hline
\end{tabular}

TABLE 3. - REACTION EFFICIENCIES OF SELECTED MATERIALS WITH ATOMIC OXYGEN IN LOW EARTH ORBIT (LEGER, 1987)

\begin{tabular}{|l|c|}
\hline \multicolumn{1}{|c|}{ Material } & $\begin{array}{c}\text { Radiation effictency, } \\
\text { CM3/atom }\end{array}$ \\
\hline Kapton & $3 \times 10^{-24}$ \\
Myler & $3.4 \times 10^{-24}$ \\
Tedlar & $3.2 \times 10^{-24}$ \\
Polyethylene & $3.7 \times 10^{-24}$ \\
Polysulfone & $2.4 \times 10^{-24}$ \\
Graphie/Epoxy & $--1 \times 10^{-24}$ \\
1034C & $2.1 \times 10^{-24}$ \\
Epos/T300 & $2.6 \times 10^{-24}$ \\
Silicones & $1.7 \times 10^{-24}$ \\
PTFE & $<1.7 \times 10^{-24}$ \\
Carbon (vartous forms) & $<0.05 \times 10^{-24}$ \\
Silver & 0.9 to $1.7 \times 10^{-24}$ \\
\hline
\end{tabular}


TABLE 4. - TRIBOLOGICAL BEHAVIOR OF PLASTIC GEARS (STEVENS, 1984).

\begin{tabular}{|c|c|c|c|c|c|c|c|c|}
\hline \multirow[t]{2}{*}{ Test } & \multicolumn{2}{|c|}{ Materlals } & \multirow{2}{*}{$\begin{array}{l}\text { Tooth } \\
\text { load, } \\
\text { N } / \mathrm{mm}\end{array}$} & \multirow{2}{*}{$\begin{array}{l}\text { Pinton } \\
\text { speed, } \\
\text { rpm }\end{array}$} & \multirow[t]{2}{*}{ Lubricant } & \multirow{2}{*}{$\begin{array}{l}\text { Total } \\
\text { pinion } \\
\text { revs }\end{array}$} & \multicolumn{2}{|c|}{$\begin{array}{l}\text { Tooth fiank wear rate, } \\
\text { mm depth per encounter }\end{array}$} \\
\hline & Pinion & Whee is & & & & & Pinion & Whee is \\
\hline $\begin{array}{l}2 \\
3 \\
4 \\
5 \\
6 \\
7 \\
8 \\
9 \\
10\end{array}$ & $\begin{array}{l}\text { Carbon } \\
\text { fibre } \\
\text { inpoly- } \\
\text { acetal }\end{array}$ & $\begin{array}{l}\text { Stain- } \\
\text { less } \\
\text { steel } \\
\quad\end{array}$ & $\begin{array}{l}d_{21} 1 \\
(60) \\
\\
21 \\
21 \\
21 \\
21 \\
21 \\
21 \\
7(35) \\
3(23) \\
1(13)\end{array}$ & $\begin{array}{r}50 \\
50 \\
100 \\
200 \\
500 \\
1000 \\
1000 \\
1000 \\
1000\end{array}$ & Dry & $\begin{array}{r}3 \times 10^{5} \\
5 \times 10^{5} \\
7 \times 10^{5} \\
16 \times 10^{5} \\
30 \times 10^{5} \\
60 \times 10^{5} \\
30 \times 10^{5} \\
30 \times 10^{5} \\
30 \times 10^{5}\end{array}$ & $\begin{array}{r}7 \times 10^{-8} \\
7 \times 10^{-8} \\
2 \times 10^{-8} \\
5 \times 10^{-9} \\
6 \times 10^{-9} \\
5 \times 10^{-9} \\
b_{3} 5 \times 10^{-9} \\
b_{2} 2 \times 10^{-9} \\
b_{1 \times 10^{-9}}\end{array}$ & Zero \\
\hline $\begin{array}{l}12 \\
13 \\
14 \\
15 \\
16 \\
17 \\
18 \\
19 \\
20\end{array}$ & $\begin{array}{l}\text { Vespel } \\
\text { SP31 }\end{array}$ & $\begin{array}{l}\text { Stain- } \\
\text { less } \\
\text { steel } \\
1\end{array}$ & $\begin{array}{l}\downarrow \\
7(30) \\
3(20) \\
1(10)\end{array}$ & $\begin{array}{r}50 \\
\\
50 \\
50 \\
100 \\
200 \\
500 \\
1000 \\
1000 \\
1000 \\
1000\end{array}$ & Dry & $\begin{array}{r}5 \times 10^{4} \\
\\
3 \times 10^{5} \\
5 \times 10^{5} \\
7 \times 10^{5} \\
16 \times 10^{5} \\
30 \times 10^{5} \\
60 \times 10^{5} \\
30 \times 10^{5} \\
30 \times 10^{5} \\
30 \times 10^{5}\end{array}$ & $\begin{array}{l}1 \times 10^{-8} \\
7 \times 10^{-9} \\
7 \times 10^{-9} \\
9 \times 10^{-9} \\
6 \times 10^{-9} \\
5 \times 10^{-9} \\
4 \times 10^{-9} \\
3 \times 10^{-9} \\
2 \times 10^{-9} \\
1 \times 10^{-9}\end{array}$ & Zero \\
\hline $\begin{array}{l}22 \\
23 \\
24\end{array}$ & $\begin{array}{l}\text { Vespe I } \\
\text { SP8 }\end{array}$ & $\begin{array}{l}\text { Stain- } \\
\text { less } \\
\text { Steel }\end{array}$ & 7 & $\begin{array}{l}200 \\
200 \\
200\end{array}$ & $\begin{array}{l}\text { Dry } \\
\text { Dry } \\
\text { BPI10 } \\
\text { BPI10 }\end{array}$ & $\begin{array}{r}1 \times 10^{5} \\
40 \times 10^{5} \\
1 \times 10^{5} \\
40 \times 10^{5}\end{array}$ & $\begin{array}{l}4 \times 10^{-8} \\
4 \times 10^{-9} \\
8 \times 10^{-8} \\
4 \times 10^{-9}\end{array}$ & Zero \\
\hline
\end{tabular}

a Tooth contact stress in $\mathrm{N} / \mathrm{mm}^{2}$.

bsteady state wear rate after running-in wear completed. 
TABLE 5. - TORQUE RESULTS FROM BEARING TESTS CONDUCTED IN VACUUM USING METALLIC CAGES COATED WITH SPUTTERED MOS 2 Or ION-PLATED LEAD AND WITH PTFE-COMPOSITE CAGES (BRISCOE AND TODD, 1983).

[Bearing lives with MOS 2 -sputtered fllm varied from 0.7 to $3 \times 10^{6}$ revs for films sputtered at ESTL to $3.6 \times 10^{6}$ revs for films from LSRH, Switzerland.

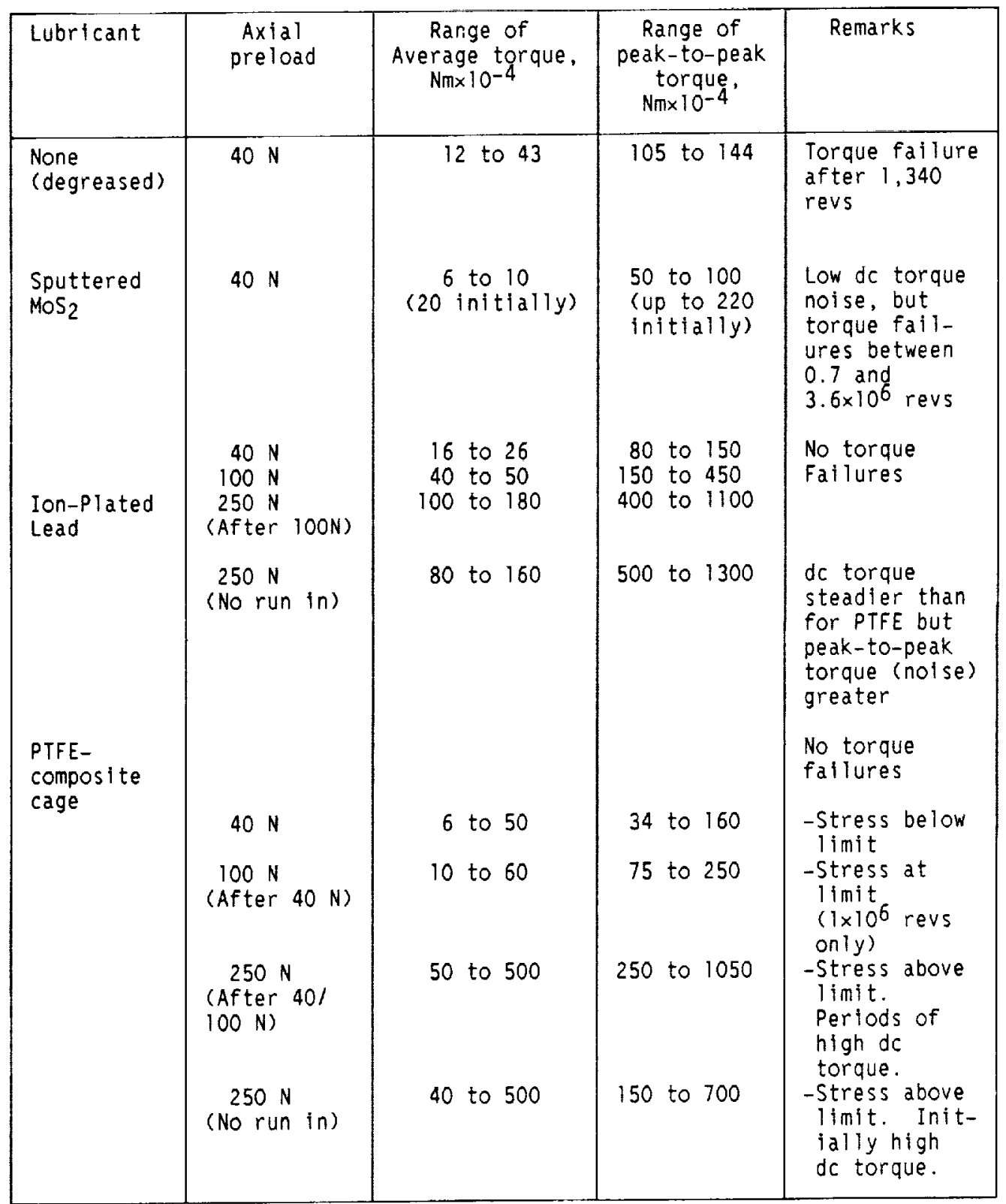


TABLE 6. - PROPERTIES OF PTFE FORMULATED COMPOSITE BEARING CAGES EVALUATED IN EARLY NASA CRYOGENIC BEARING TESTS (BREWE, 1966).

\begin{tabular}{|c|c|c|c|}
\hline $\begin{array}{l}\text { Bearing } \\
\text { designa- } \\
\text { tion }\end{array}$ & Cage material & $\begin{array}{c}\text { Composition, } \\
\text { wt } \%\end{array}$ & Cage construction \\
\hline$A$ & \multirow{2}{*}{$\begin{array}{l}\text { Laminated-glass } \\
\text { cloth with PTFE } \\
\text { binder }\end{array}$} & \multirow{2}{*}{$\begin{array}{l}38 \text { percent glass cloth } \\
\text { laminates with } 62 \text { per- } \\
\text { cent PTFE binder }\end{array}$} & \multirow{2}{*}{$\begin{array}{l}\text { One-plece body } \\
\text { with rivited } \\
\text { aluminum side } \\
\text { plates }\end{array}$} \\
\hline B & & & \\
\hline C & \multirow{2}{*}{$\begin{array}{l}\text { Glass-fiber- } \\
\text { molybdenum disulfide } \\
\text { filled PTFE }\end{array}$} & \multirow{2}{*}{$\begin{array}{l}15 \text { percent glass } \\
\text { fibers, } 5 \text { percent } \\
\text { molybdenum disulfide, } \\
80 \text { percent PTFEa }\end{array}$} & \multirow{2}{*}{$\begin{array}{l}\text { One piece body } \\
\text { with no external } \\
\text { support }\end{array}$} \\
\hline D & & & \\
\hline$E$ & \multirow[t]{2}{*}{$\begin{array}{l}\text { Glass-fiber-fllled } \\
\text { PTFE }\end{array}$} & \multirow[t]{2}{*}{$\begin{array}{l}15 \text { to } 20 \text { percent } \\
\text { glass fibers, balance } \\
\text { PTFE }\end{array}$} & \multirow{2}{*}{$\begin{array}{l}\text { One-plece body } \\
\text { with one-plece } \\
\text { rivited aluminium } \\
\text { shroud }\end{array}$} \\
\hline$F$ & & & \\
\hline G & \multirow[t]{2}{*}{ Bronze-fllled PTFE } & \multirow{2}{*}{$\begin{array}{l}30 \text { percent bronze } \\
\text { powder, } 70 \text { percent } \\
\text { PTFE }\end{array}$} & \multirow{2}{*}{$\begin{array}{l}\text { One-plece body } \\
\text { with no external } \\
\text { support }\end{array}$} \\
\hline $\mathrm{H}$ & & & \\
\hline
\end{tabular}

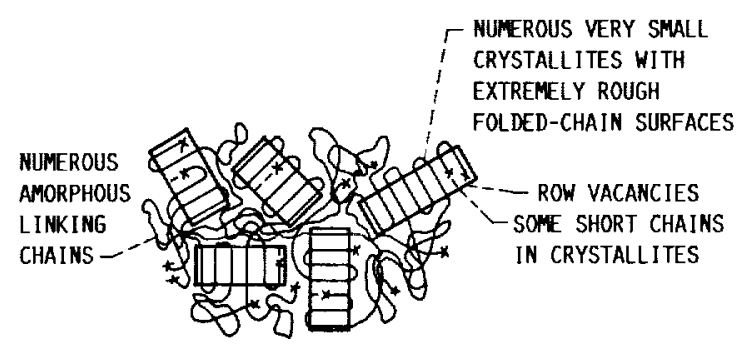

(a) QUENCH CRYSTALLIZED.

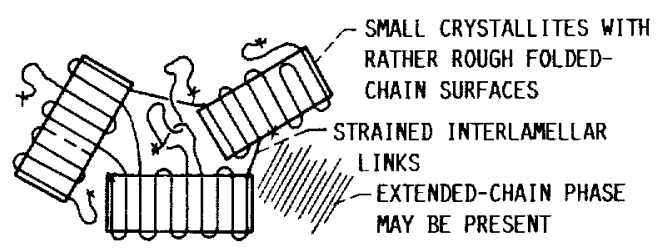

(b) QUENCH CRYSTALLIZED AND ANNEALED,

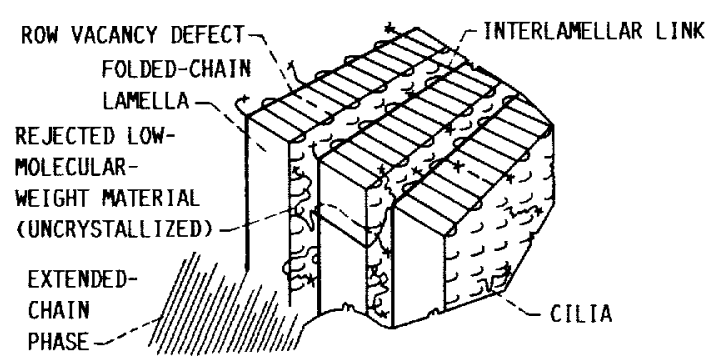

(c) ISOTHERMALLY CRYSTALLIZED NEAR MELTING POINT.

FIGURE 1. - SCHEMATIC REPRESENTATION OF FINE STRUCTURE OF A POL YMER PREPARED UNDER DIFFERENT CRYSTALLIZATION CONDITIONS (HOFFMAN, 1966). 
ORIGINAL PAGE

BLACK AND WHITE PHOTOGRAPH

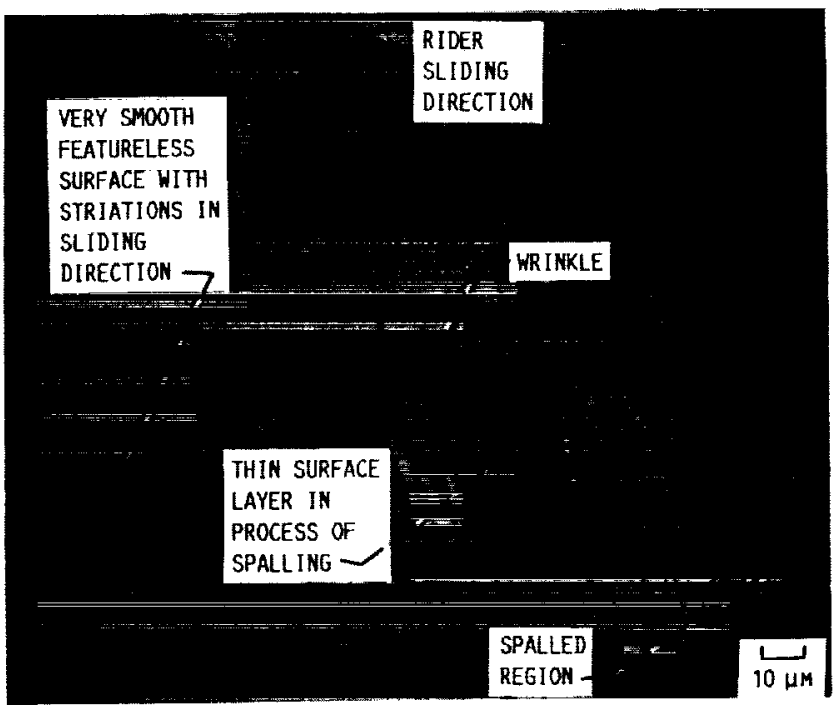

FIGURE 2. - HIGH MAGNIFICATION PHOTOMICROGRAPH OF A PIC-1 POLYIMIDE FILM WEAR TRACK AT $150^{\circ} \mathrm{C}$ IN DRY AIR $\left(<100\right.$ PPM H $\left.\mathrm{H}_{2} 0\right)$ ILLUSTRATING THE SLIDING SURFACE MORPHOLOGY AT A TEMPERATURE ABOVE THE TRANSITION (FUSARO, 1978).

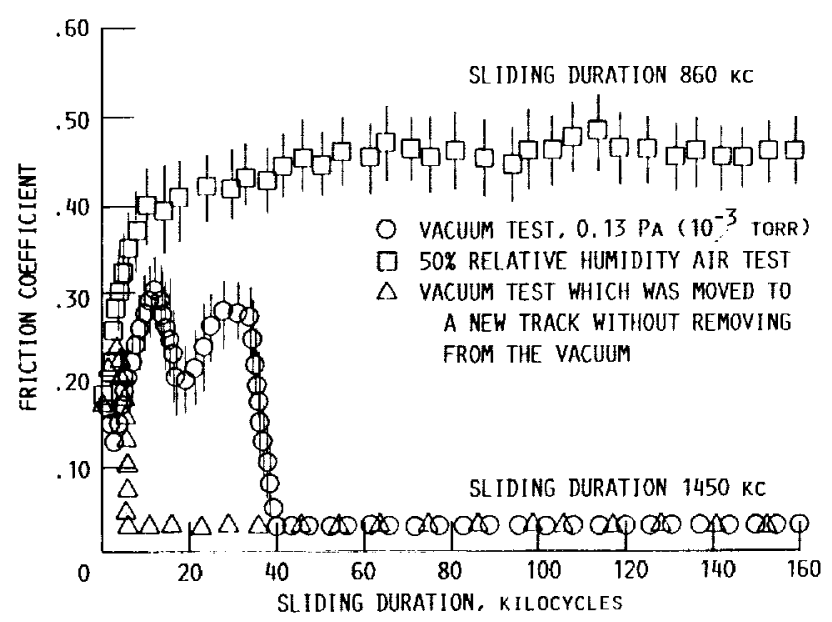

FIGURE 3. - COMPARISON OF THE FRICTION PROPERTIES OF A COMMERCINLLY AVAILABLE POLYIMIDE SOLID BODY IN VACUUM AND IN 50 PERCENT RELATIVE HUMIDITY AIR (FUSARO, 1988). 


\section{ORIGINAL PAGE \\ BLACK AND WHITE PHOTOGRAPH}

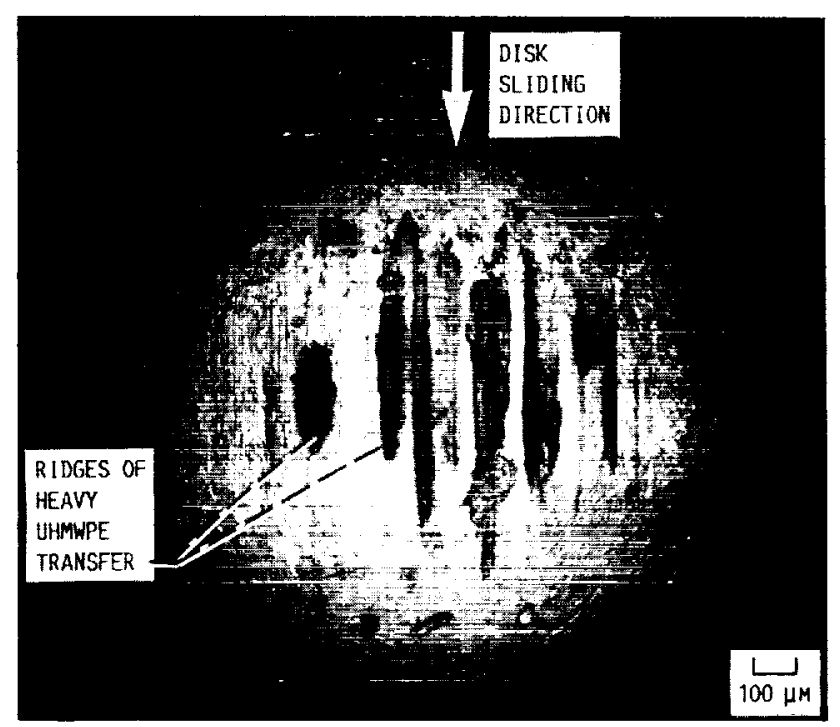

(a) $100 \mathrm{KC}$ OF SLIDING AT $100 \mathrm{RPM}$.

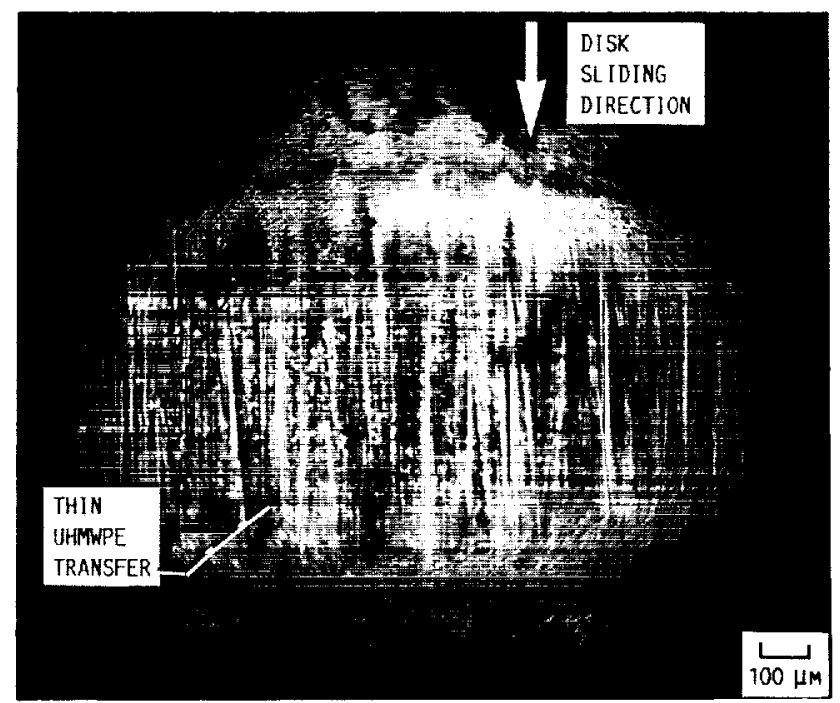

(b) $3000 \mathrm{KC}$ OF SLIDING AT $800 \mathrm{RPM}$.

FIGLRE 4. - PHOTOMICROGRAPHS OF TRANSFER TO METALLIC PINS FROM UHMWPE DISKS SLIDING IN 50 PERCENT HUMIDITY AIR AT $25 \mathrm{C}$ (FUSARO, 1982). 


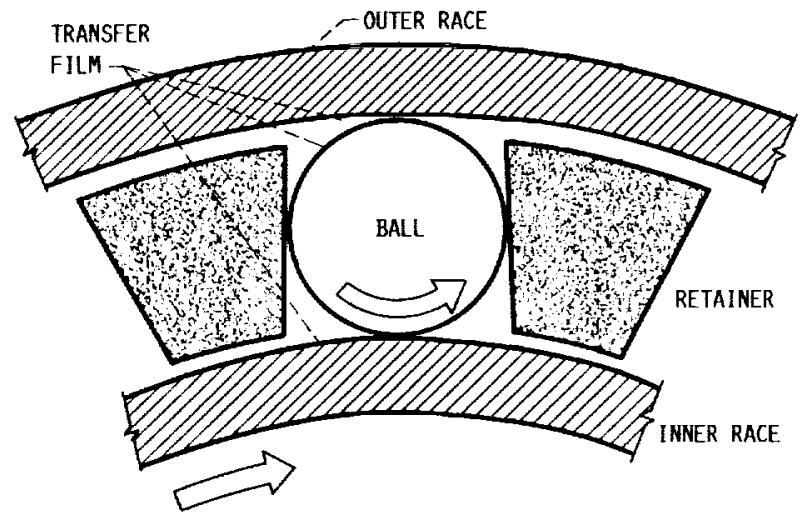

FIGURE 5. - SCHEMATIC ILLUSTRATION OF BALL BEARING FILM TRANSFER MECHANISM (BREWE, 1966).

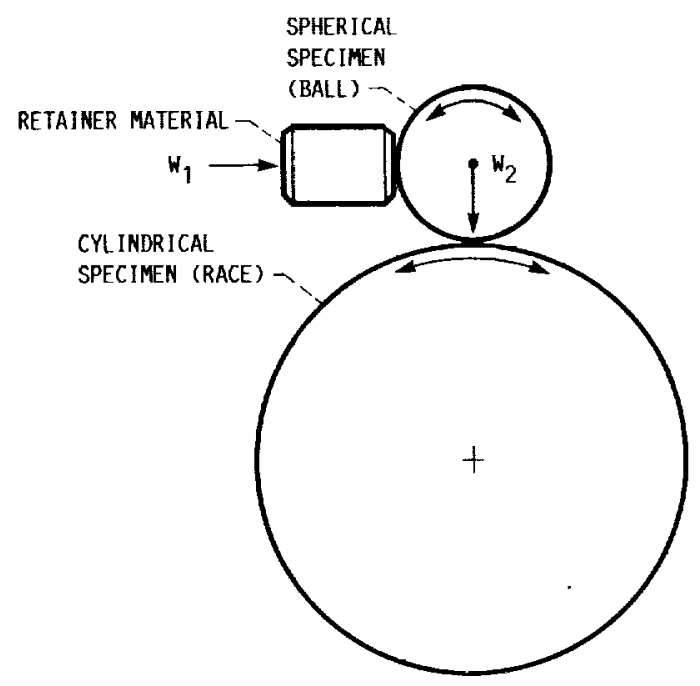

FIGURE 6. - SCHEMATIC DRAWING OF APPARATUS FOR TRANSFER ANALYSIS (KANNEL AND FUFRANE, 1986).

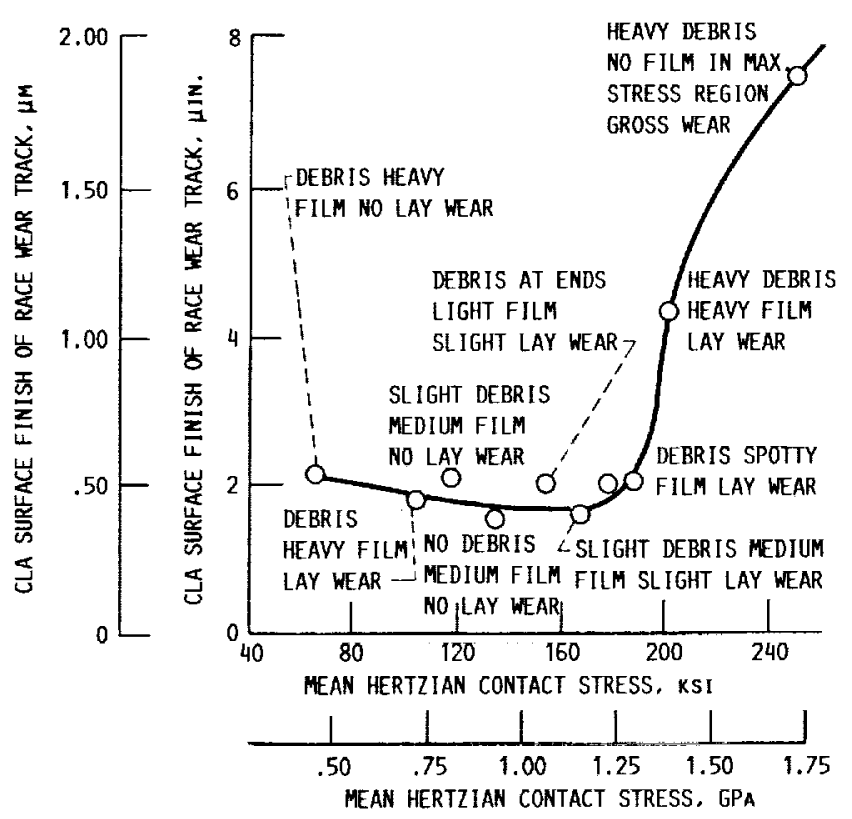

FIGURE 7. - RELATIONSHIP BETWEEN RACE WEAR TRACK SURFACE FINISH AND BALL-RACE CONTACT STRESS FOR A RACE LUBRICATED WITH A RULON-A + 5 PERCENT NOS, TRANSFER FILM (KANNEL, 1986). 


\section{ORIGINAL PAGE IS \\ OF. POOR QUALITY}

ORIGINAL PAGE

BLACK AND WHITE PHOTOGRAPH

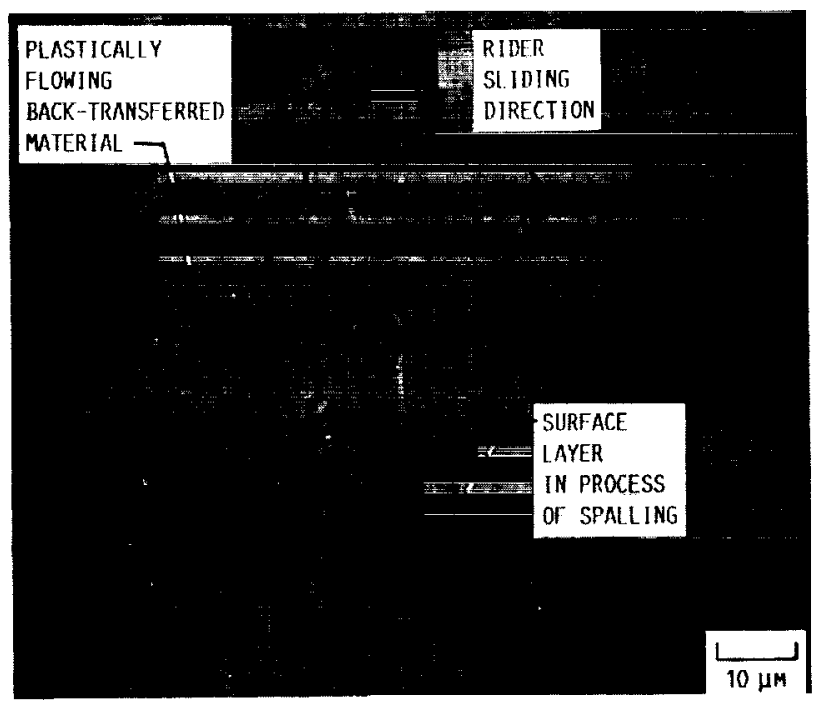

(a) SCALING OF TIIIN SURFACE LAYERS.

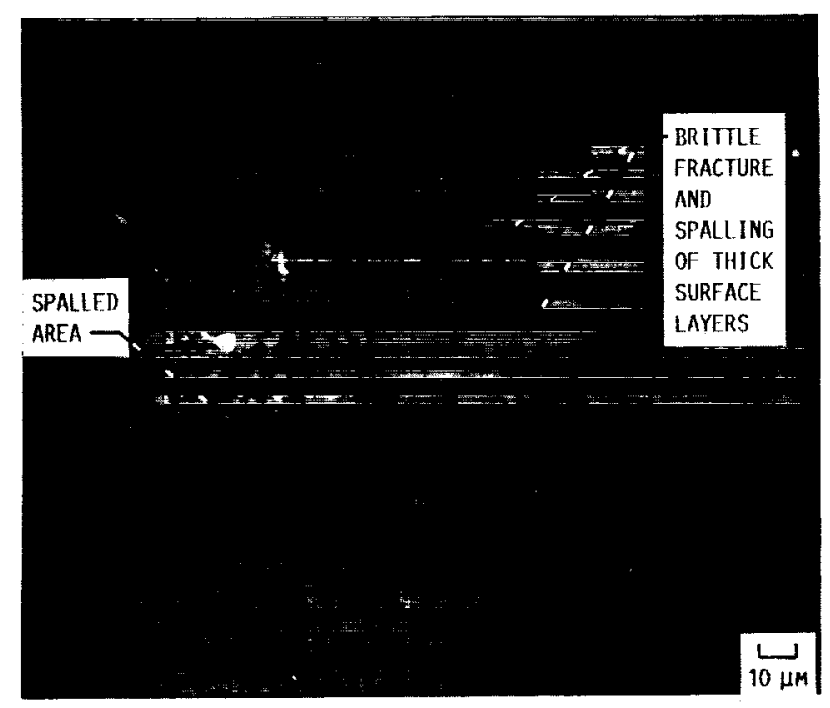

(b) BRITTIE. FRACTIJRE OF TIIICK SURFACE LAYERS.

FIGURE 8. - PHOTOMICROGRAPIS OT SURTACE MIRPHOLOGY ON THE WEAR TRACKS OF POLYIMIDE- BONDED GRAPHITE FLUORIDE FILMS SUBJECTED TO LOW CONTACT STRESSES (14 MPA) ILLUSTIATING WEAR MECHANISMS (FUSARO, 1981).

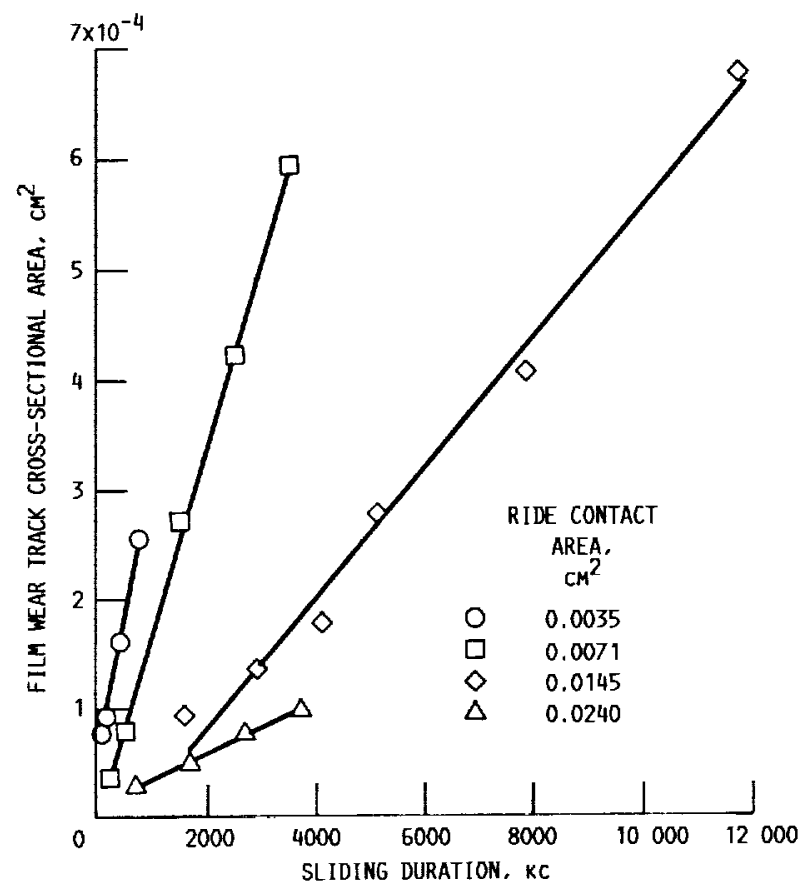

FIGURE 9. - PHOTOMICROGRAPHS OF TRANSFER FROM A GRAPHITE FIBER REINFORCED POLYIMIDE PIN TO A VITALLIUM DISK AFTER (a) 1 KILOMETER, AND (b) 500 KILOMETER OF SLIDING IN A 50 PERCENT RELATIVE HUMIDITY AIR ATMOSPHERE AT 25 C (FUSARO, 1985). 

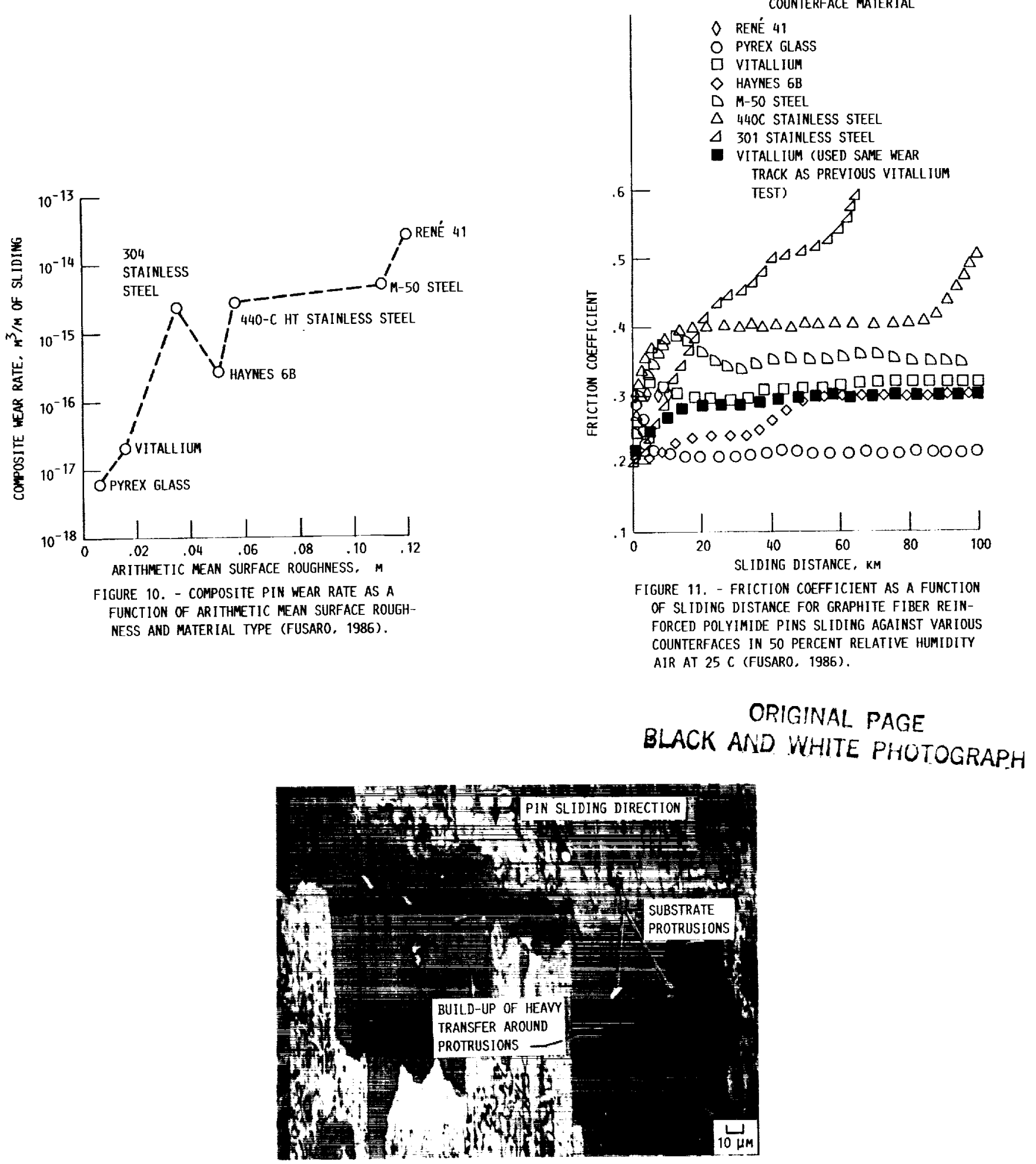

FIGURE 12. - PHOTOMICROGRAPHS OF TRANSFER FROM A GRAPHITE FIBER REINFORCED POLYIMIDE TO A RENÉ 41 DISK COUNTERFACE AFTER 1 KILOMETER OF SLIDING IN A 50 PERCENT RELATIVE HUMIDITY AIR ATMOSPHERE AT 25 C (FUSARO, 1986). 


\section{ORIGINAL PAGE IS \\ OF POOR QUALITY}

\section{ORIGINAL PAGE \\ BLACK AND WHITE PHOTOGRAPH}

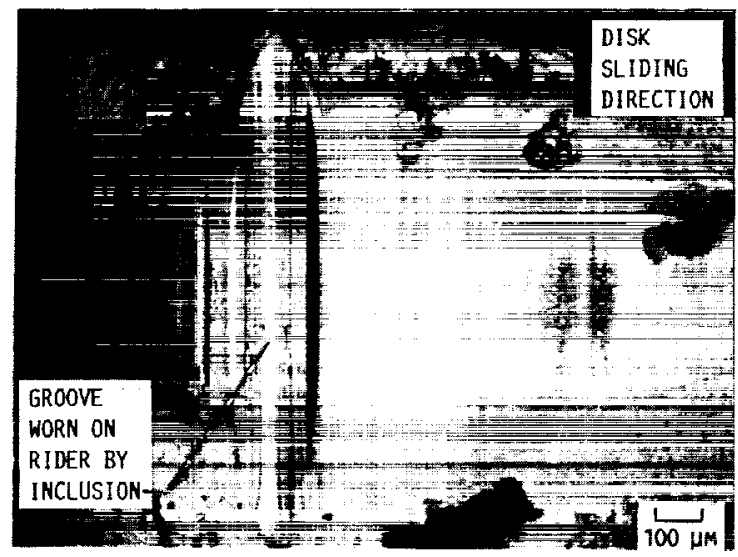

(a) PHOTOMICROGRAPH OF METALLIC PIN CONTACT AREA.

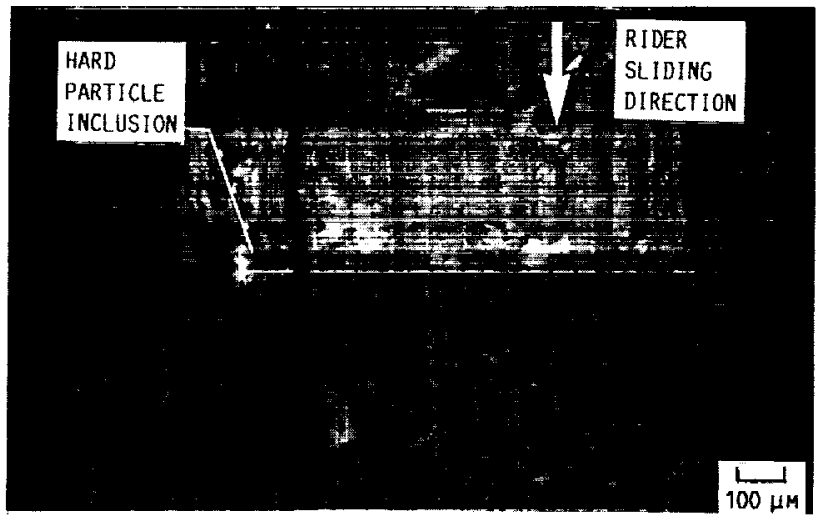

(b) PHOTOMICROGRAPH OF UHMWPE DISK WEAR TRACK.

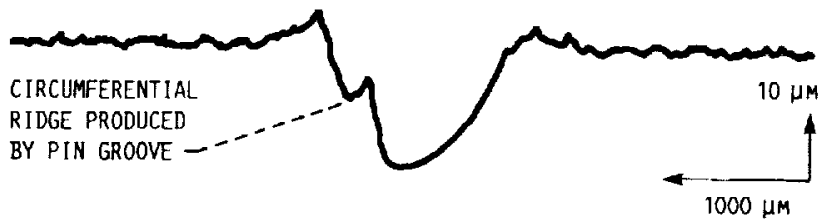

(c) SURFACE PROFILE OF UHMWPE DISK WEAR TRACK.

FIGURE 13. - PHOTOMICROGRAPHS AND A SURFACE PROFILE OF THE SLIDING CONTACT AREAS ILLUSTRATING THE WEAR CAUSED BY AN EMBEDDED HARD PARTICLE IN THE UHMWPE DISK.

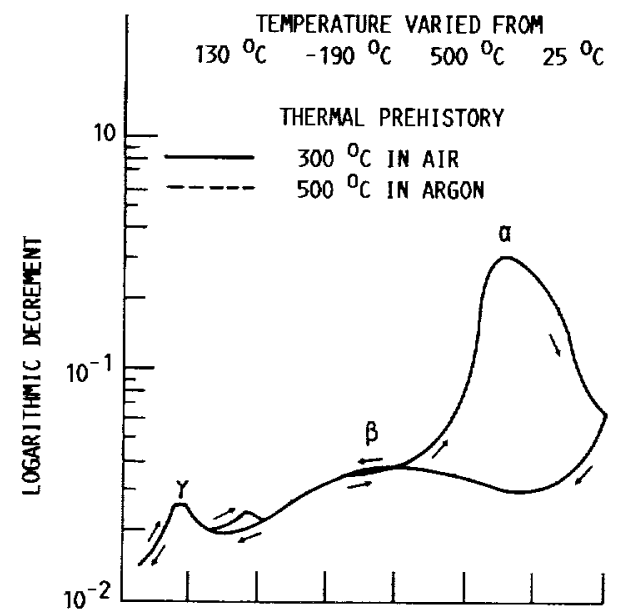

(a) LOGARITHMIC DECREMENT.

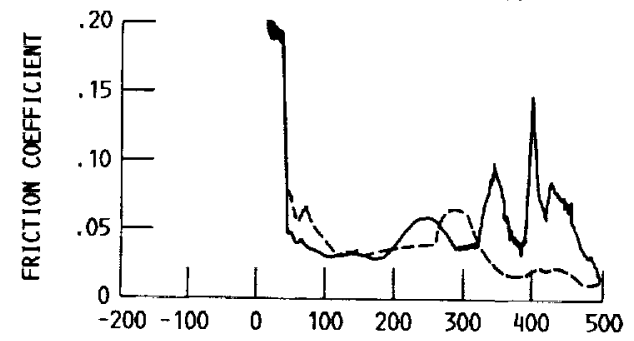

(b) FRICTION COEFFICIENT.

FIGURE 14. - COMPARISON OF THE LOGARITHMIC DECREMENT (A RATIO OF THE ENERGY DISSIPATED TO THE MAXIMUM ENERGY STORED DUR ING MECHANICAL DEFORMATION) AND THE FRICTION COEFFICIENT AS A FUNCTION OF TEMPERATURE IN DRY ARGON FOR A CONERCIALLY AVAILABLE POLYIMIDE FILM (FUSARO, (1975). 


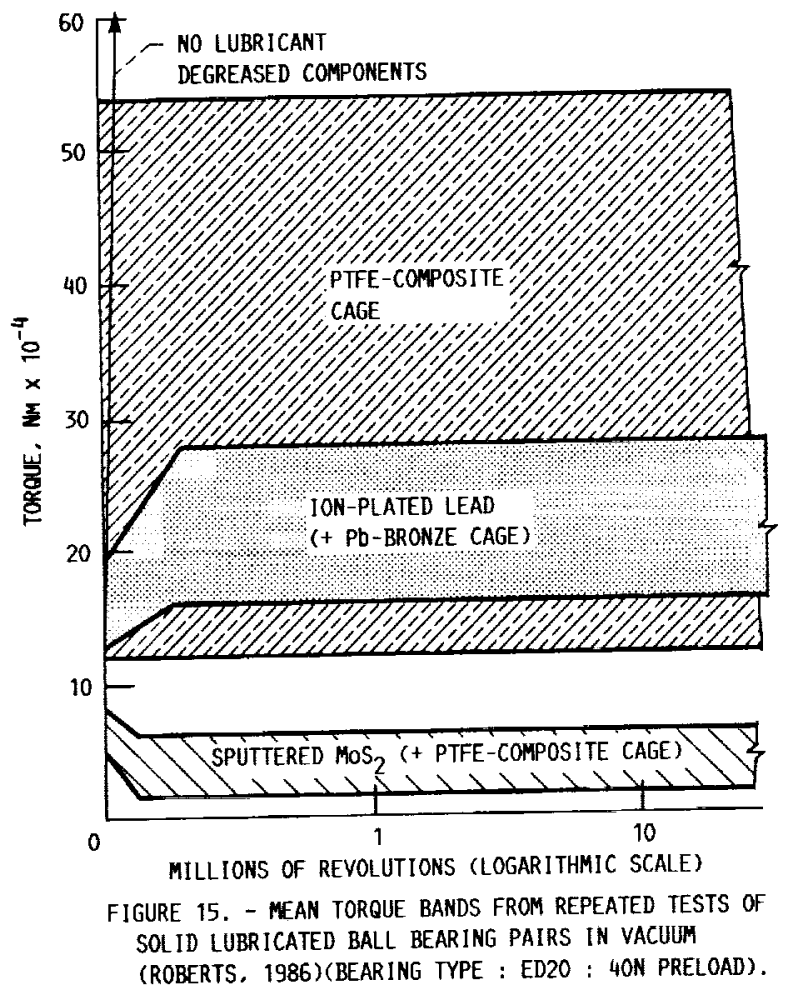




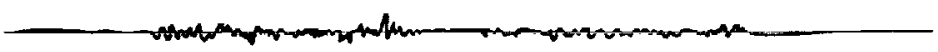

(a) RUN TINE, O MINUTES.

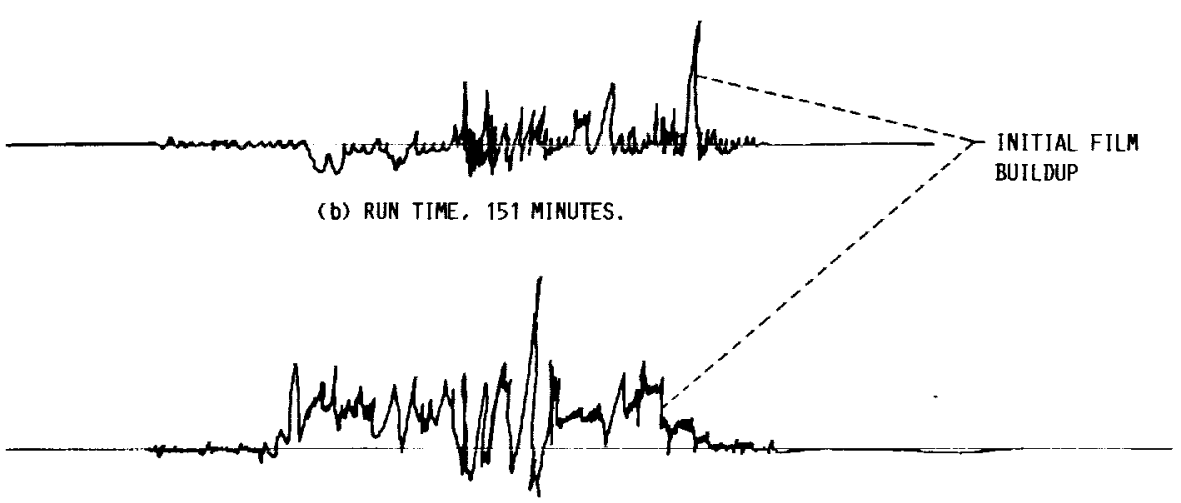

(c) RUN TIME, 284 MINUTES.

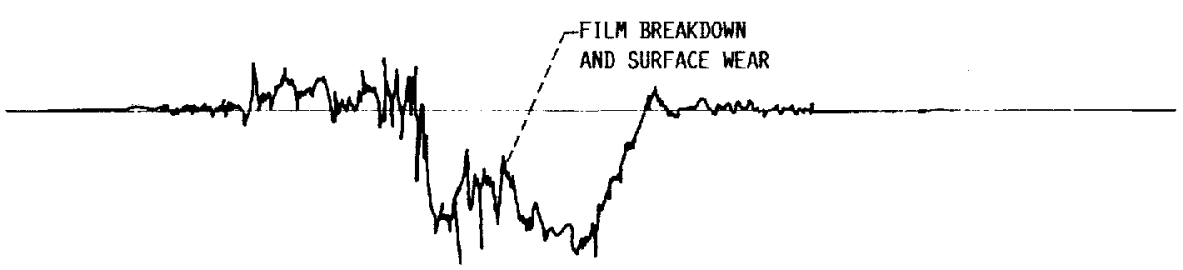

(d) RUN TIME, 404 MINUTES.

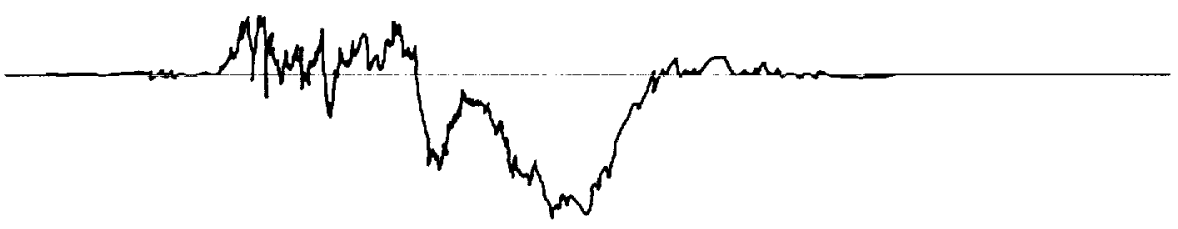

(e) RUN TIME, 520 MINUTES,

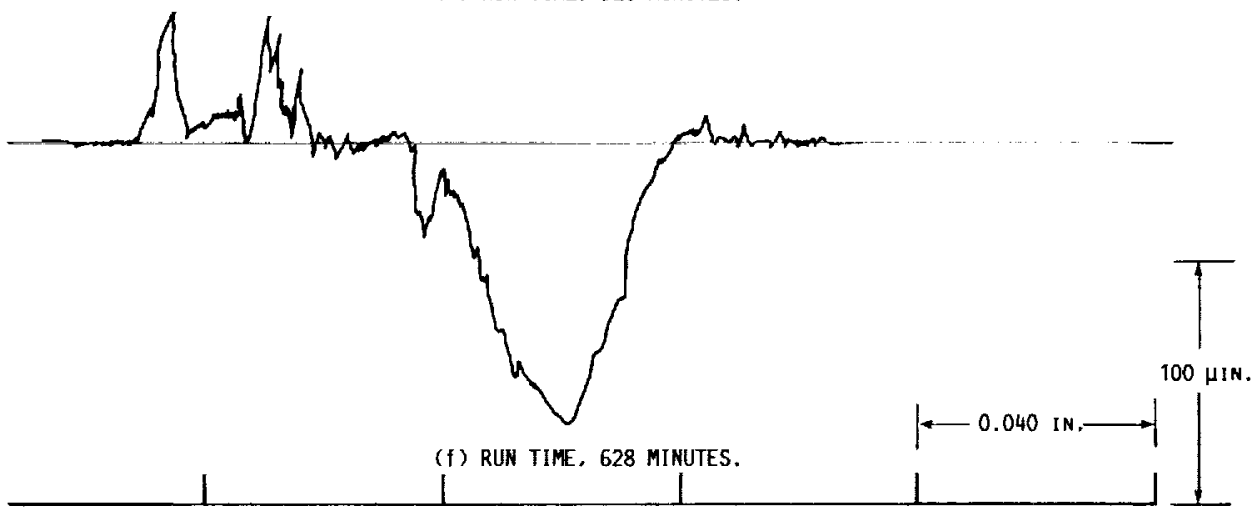

FIGURE 16. - PROGRESSIVE PROFILE TRACES OF INNER-RACE GROOVE OF BEARING A WITH A LAMINATED-GLASS CLOTH WITH PTFE BINDER CAGE MATERIAL. SHAFT SPEED, 20000 RPM; THRUST LOAD, 200 POUNDS; COOLANT, HYDROGEN GAS AT $60{ }^{\circ}$ R (BREWE, 1986). 


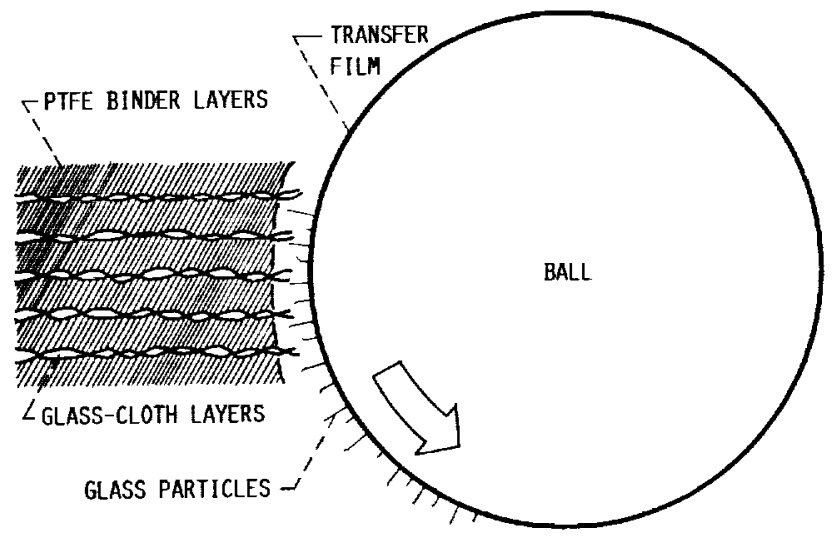

FIGURE 17. - POSTULATED WEAR PROCESS OF HOW GLASS FIBERS FROM A LAMINATED GLASS-CLOTH WITH PTFE BINDER RETAINER WEAR THE RACES OF A BALL BEARING (BREWE, 1966).

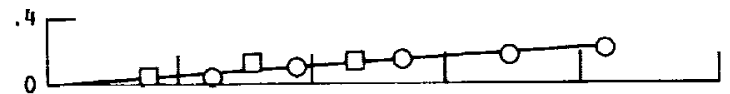

(a) LAMINATED GLASS CLOTH WITH PTFE BINDER.

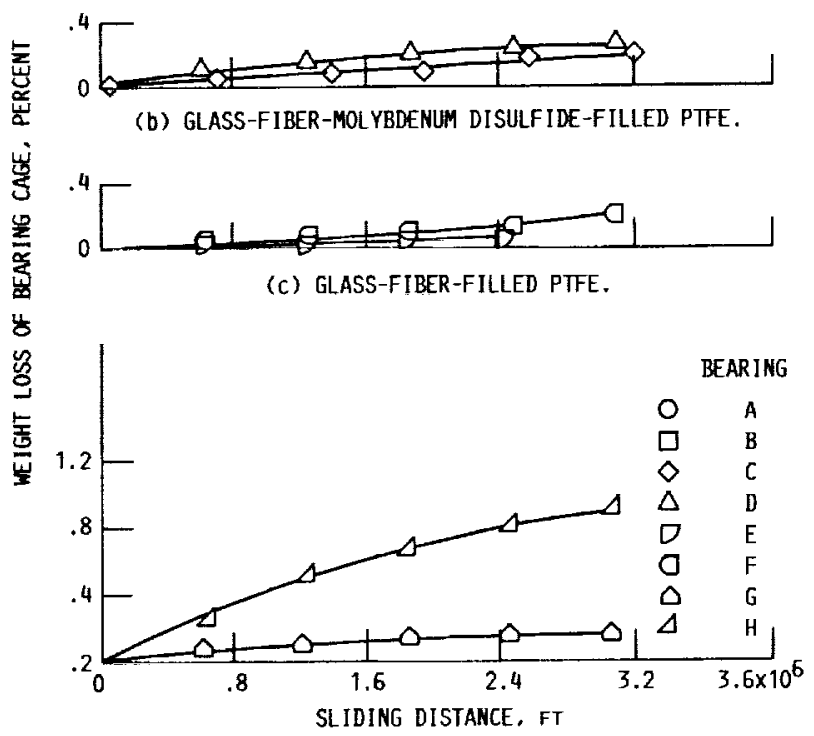

(d) BRONZE-FILLED PTFE.

FIGURE 18. - BEARING CAGE WEIGHT LOSS AS A FUNCTION OF SLIDING DISTANCE RELATIVE TO THE INMER RACE FOR TESTS GUN IN GASEOUS HYDROGEN AT $33 \mathrm{~K}$. SHAFT SPEED, 20000 RPM, THRUST LOAD, $900 \mathrm{~N}(200$ LB) (BREWE, 1966). 


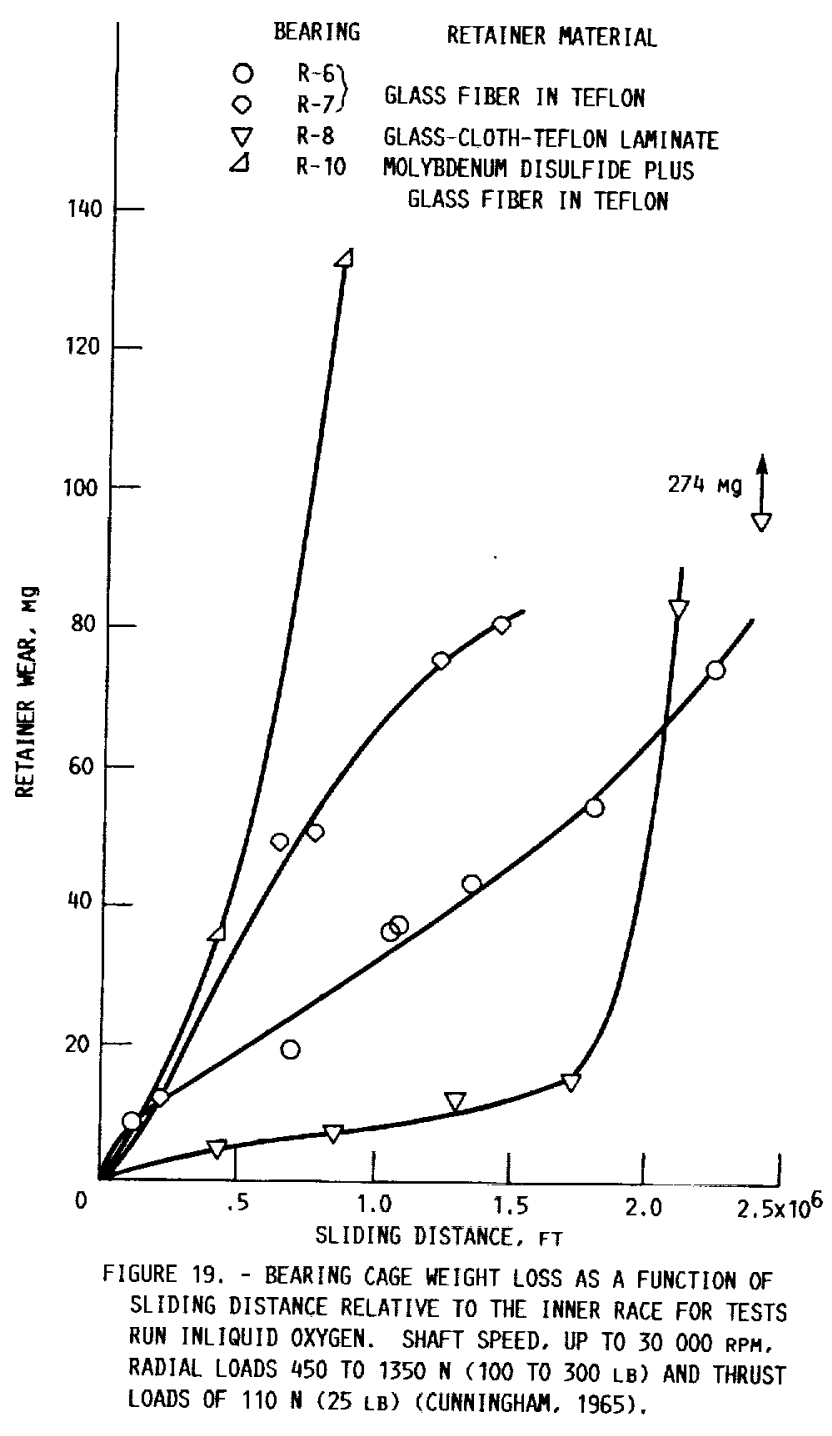




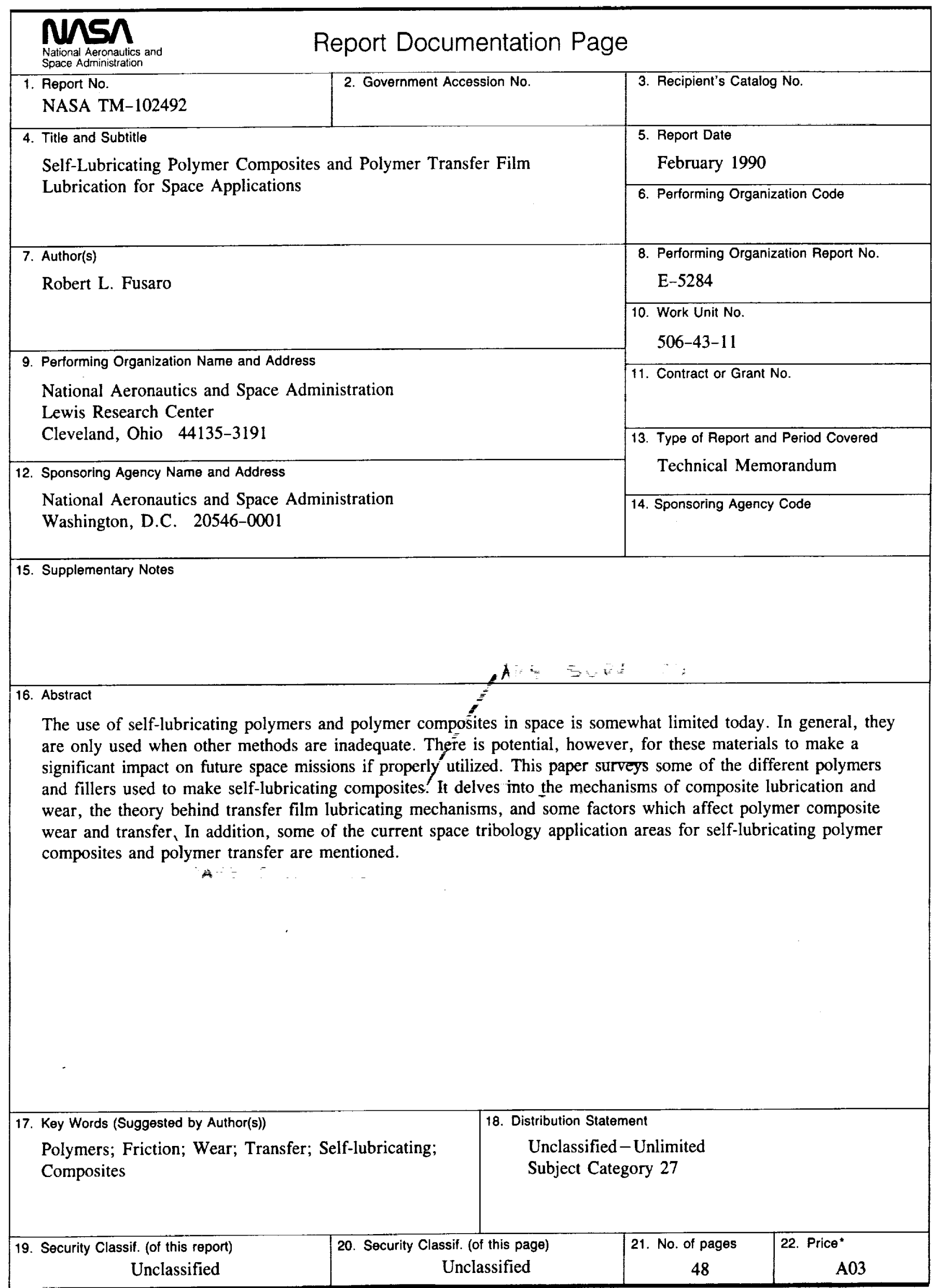


National Aeronautics and Space Administration

Lewis Research Center Cleveland, Ohio 44135

Officiat Business

Penalty for Private Use $\$ 300$
FOURTH CLASS MÃIL

ADDRESS CORRECTION REQUESTED
|||||

National Aeronaulcs and

Spare Adringitration

NASA 45 
